\title{
Large and local-scale influences on physical and chemical characteristics of coastal waters of Western Europe during winter
}

\author{
Paul Tréguer ${ }^{a, *}$, Eric Goberville ${ }^{b}$, Nicolas Barrier ${ }^{c}$, Stéphane L'Helguen ${ }^{a}$, Pascal Morin ${ }^{d}$, Yann Bozec ${ }^{d}$, \\ Peggy Rimmelin-Maury ${ }^{a}$, Marie Czamanski ${ }^{a}$, Emilie Grossteffan ${ }^{a}$, Thierry Cariou ${ }^{d}$, Michel Répécaud ${ }^{\mathrm{e}}$, \\ Loic Quéméner
}

\author{
a UMR 6539 LEMAR and UMS OSU IUEM-UBO, Université Européenne de Bretagne, Brest, France \\ b Université Lille 1 - UMR 8187 LOG, Laboratoire d'Océanologie et de Géosciences, 28 Avenue Foch, F-62930 \\ Wimereux, France \\ ${ }^{c}$ UMR 6523 LPO IUEM-Ifremer, Université Européenne de Bretagne, Brest, France \\ ${ }^{d}$ OSU SBR-UPMC, Roscoff, France \\ ${ }^{\mathrm{e}} \mathrm{REM} / \mathrm{RDT} / \mathrm{DCM}$, Ifremer Centre de Brest
}

*: Corresponding author : Paul Tréguer, tel.: + 33608480750 ; email address : paul.treguer@univ-brest.fr

\begin{abstract}
:
There is now a strong scientific consensus that coastal marine systems of Western Europe are highly sensitive to the combined effects of natural climate variability and anthropogenic climate change. However, it still remains challenging to assess the spatial and temporal scales at which climate influence operates. While large-scale hydro-climatic indices, such as the North Atlantic Oscillation (NAO) or the East Atlantic Pattern (EAP) and the weather regimes such as the Atlantic Ridge (AR), are known to be relevant predictors of physical processes, changes in coastal waters can also be related to local hydro-meteorological and geochemical forcing. Here, we study the temporal variability of physical and chemical characteristics of coastal waters located at about $48^{\circ} \mathrm{N}$ over the period 1998 2013 using (1) sea surface temperature, (2) sea surface salinity and (3) nutrient concentration observations for two coastal sites located at the outlet of the Bay of Brest and off Roscoff, (4) river discharges of the major tributaries close to these two sites and (5) regional and local precipitation data over the region of interest. Focusing on the winter months, we characterize the physical and chemical variability of these coastal waters and document changes in both precipitation and river runoffs. Our study reveals that variability in coastal waters is connected to the large-scale North Atlantic atmospheric circulation but is also partly explained by local river influences. Indeed, while the NAO is strongly related to changes in sea surface temperature at the Brest and Roscoff sites, the EAP and the AR have a major influence on precipitations, which in turn modulate river discharges that impact sea surface salinity at the scale of the two coastal stations.
\end{abstract}

\section{Highlights}

The variability of coastal waters is related to large and local-scale forcing Teleconnection patterns and weather regimes explain the coastal waters variability $>$ North Atlantic Oscillation and East Atlantic Pattern impact European coastal waters - The weather regimes explain the variability of European coastal waters during winter

Keywords : Coastal systems ; Climate variability ; Large-scale hydro-climatic indices ; River inputs ; Time-series ; Weather regimes 


\section{Introduction}

Coastal systems are among the most important systems of the ocean both ecologically and economically (Costanza, 1997) and the influence of global, regional and local climatedriven processes on the variability of their physical, chemical and biological characteristics is now well documented (e.g. Goberville et al., 2010; Harley et al., 2006). However, coastal areas are highly complex and dynamic ecosystems. The response of coastal systems to climate influence could occur in a nonlinear way (Breton et al., 2006) and cross-scale interactions, by changing the pattern-process relationships across scales, could have important influences on ecosystems processes (Peters et al., 2007). Assessing and quantifying the relative contributions of both large-scale and local-scale processes to this variability remains therefore challenging and of paramount importance to better detect, understand and anticipate potential changes in the state of coastal systems in the context of climate change (Harley et al., 2006).

The coastal systems of Western Europe are interesting case studies. At a large scale, they are connected to the eastern boundary current (e.g. Arhan et al., 1994) fed by the North Atlantic drift and are impacted by the westerlies blowing over the Atlantic basin, which bring wet atmosphere to the continent. These two processes explain the typically mild winters in Western Europe (e.g. Bojariu and Reverdin, 2002; Garavaglia et al., 2010; Guintoli et al., 2013; Seager et al., 2002). At a local scale, the region is characterized by intensive weathering of rocks and soils due to abundant precipitation, especially during winter. Winter precipitation generates intensive nutrient loadings from the terrestrial realm to the aquatic system (Dürr et al., 2011; Meybeck et al., 2006; Tréguer and De La Rocha, 2013) and contributes to high nutrient standing stocks in coastal waters. These high nutrient concentrations directly support large phytoplankton blooms during the spring period (e.g. Beucher et al., 2004; Del Amo et al., 1997; Quéguiner and Tréguer, 1984). According to the Intergovernmental Panel on Climate Change (2007), the projected global increase in temperature could result in a number of impacts on the hydrological cycle, including changes in precipitation (Labat et al., 2004). Precipitation rate could be directly influenced by changes in atmospheric circulation and the increase in evaporation associated with warmer temperatures (Labat et al., 2004). As a consequence, changes in continental runoff and associated river discharges of nutrients are expected, placing potential further stress on coastal systems already affected by eutrophication (Diaz and Rosenberg, 1995; Dussauze and Ménesguen, 2008; Selman et al., 2008). 
In this study, we examined the contribution of large-scale and local-scale processes to the physical and chemical variability of the coastal waters of two macrotidal systems. The study region is located at about $48^{\circ} \mathrm{N}$ and adjacent to the Armorican peninsula (in Western Europe; Fig. 1): the Bay of Brest and the Roscoff coastal zone. These two sites present local hydro-climatological and topographic peculiarities. First, both topographic (i.e. low altitude) and geologic constraints (impermeable rocks mostly unbroken; Mougin et al., 2008) limit the catchments' areas. Second, the small surface area of the catchments causes them to feed small streams and, in opposition to estuarine waters, these coastal waters remain almost marine (Delmas et al., 1983; Le Jehan et al., 1984). We first described the physical (temperature and salinity), chemical (nutrients) and hydrological (precipitation and river discharge) variability in the two coastal sites from 1998 onwards, using data from four monitoring programs: (1) the Service d'Observation en Milieu LITtoral (SOMLIT program) (2) the Mesures Automatisées en Réseau pour l'Environnement et le Littoral (MAREL observing network), (3) the ECOFLUX network and (4) the Meteo-France network. These monitoring programs are described in some detail in the next section. Focusing on the winter months (DecemberJanuary-February; hereafter DJF), we then investigated as to what extent large-scale and local-scale processes influence the variability of these coastal waters. In addition to the common large-scale teleconnections (e.g. the NAO), we also consider winter weather regimes indices. Weather regimes have been shown to be efficient in capturing the interannual and decadal variability of surface forcing (Cassou et al., 2011; Minvielle et al., 2011). These regimes, via their associated surface wind anomalies, may influence the ocean circulation and upper ocean properties in the North Atlantic Ocean (Barrier et al., 2013; Barrier et al., 2012; Häkkinen et al., 2011) and may affect precipitation patterns, which in turn modulate the volume of river discharge (Goberville et al., 2010; Milliman et al., 2008). However, while many studies have dealt with the influence of large-scale processes on coastal systems (e.g. Goberville et al., 2010; Harley et al., 2006), weather regimes have been seldom used to identify and quantify such forcing.

\section{Figure 1}




\section{Material and Methods}

\subsection{Environmental database}

\section{Times series at $48^{\circ} \mathrm{N}$ (western Brittany):}

SOMLIT. SOMLIT is a French marine monitoring network (http://somlit.epoc.ubordeaux1.fr). It provides more than 20 core parameters of the marine environment collected manually and analyzed in laboratory. A protocol has been established so that sampling is carried out at sub-surface and in constant tidal conditions at high tide: (1) weekly and at $-2 \mathrm{~m}$ at the Brest station (Fig. 1, 48²1'29” N, 4³3'05” W), (2) twice a month and at $-1 \mathrm{~m}$ at the Astan station (Fig. 1, 48 $46^{\prime} 40^{\prime \prime} \mathrm{N}, 3^{\circ} 56^{\prime} 15^{\prime}$ 'W). Values were obtained with a precision of about $\pm 0.02^{\circ} \mathrm{C}$ for sea surface temperature (SST) and \pm 0.005 PSS-78 (hereafter pss) for sea surface salinity (SSS). Nutrient concentrations were measured by colorimetric methods according to Tréguer and Le Corre (1976) for silicic acid and Aminot and Kerouel (2007) for nitrate. Concentrations were determined with a precision of $3 \%$ and $5 \%$ for silicic acid and nitrate, respectively. Note that the percentage of available data is not always optimal in Astan because of the dependency on meteorological conditions during sampling (Goberville et al., 2010).

MAREL. MAREL is a French marine monitoring network based on the use of an automated buoy equipped with physical and chemical sensors (www.ifremer.fr/dtmsi/programmes/marel). The MAREL-Iroise buoy (Fig. 1, http://wwwiuem.univ-brest.fr/observatoire/observation-cotiere/parametres-physico-chimiques/testpeg)

provides 6 core-parameters of the marine environment at $-2 \mathrm{~m}$ every 20 minutes in an autonomous mode $\left(48^{\circ} 21^{\prime} 29^{\prime \prime} \mathrm{N}, 4^{\circ} 33^{\prime} 05^{\prime} \mathrm{W}\right.$; for data viewing see: http://www.ifremer.fr/difMarelStanne/). The multiparameter probe is a C/T/D/TBD/DO/Fluo probe NKE equipped with an electrolysis chloration system that allows an efficient cleaning of sensors and guarantees measurement precision over a 3-month period. Quality control was conducted (1) by performing pre- and post-deployment metrology assay of sensors to examine both the linearity and the exactitude of the data and (2) by comparing MAREL-Iroise and SOMLIT-Brest data. Sea surface temperature and sea surface salinity were determined with a precision of $\pm 0.1^{\circ} \mathrm{C}$ and \pm 0.3 pss, respectively.

ECOFLUX. ECOFLUX is a river monitoring network (www-iuem.univbrest.fr/ecoflux) that collects samples at the mouth of rivers of Western Brittany on a weekly 
basis, for determination of nutrient concentrations. Water samples were collected at the subsurface (between $0 \mathrm{~m}$ and $-1 \mathrm{~m})$ and stored at $4^{\circ} \mathrm{C}$ for silicic acid or frozen $\left(-20^{\circ} \mathrm{C}\right)$ for nitrate. Nutrient concentrations were measured by colorimetric methods (see SOMLIT section). Freshwater flux of the Aulne and the Elorn rivers were gauged daily by the Agence de l'eau Loire-Bretagne (www.hydro.eaufrance.fr/). The watershed surface is $1224 \mathrm{~km}^{2}$ for the Aulne, $260 \mathrm{~km}^{2}$ for the Elorn, and $141 \mathrm{~km}^{2}$ for the Penzé. During the study period (from March 1998 to March 2013), the annual mean water discharge (Q; in $\left.\mathrm{m}^{3} \mathrm{~s}^{-1}\right)$ at the gauge station (Fig. 1) was 24.41, 5.97, and 3.22 for the Aulne, the Elorn and the Penzé, respectively. Herein, we considered the sum of the discharge of the Aulne and the Elorn rivers (hereafter named the Aulne+Elorn) to estimate the volume of water discharge to the Brest site.

\section{Times series at $50^{\circ} \mathrm{N}$ (north-western English Channel):}

To compare with the monthly variability in SST and SSS at both SOMLIT sites, we used long-term observations carried out at two stations located at about $50^{\circ} \mathrm{N}$ in the Western English Channel (Fig. 1). SST and SSS have been sampled since 1988 at the L4 station $\left(50^{\circ} 15^{\prime} \quad \mathrm{N}, \quad 4^{\circ} 13^{\prime} \quad \mathrm{W}\right)$ by the Plymouth Marine Laboratory (http://www.westernchannelobservatory.org.uk). Because sampling protocol changed in 2002, we focused on the period 2002-2012 for consistency in the analysis (Smyth et al. 2010). Values were obtained with a precision of about $+0.0018^{\circ} \mathrm{C}$ for SST and $+0.01 \mathrm{pss}$ for SSS (Smyth et al. 2010). In addition, we used SST data recorded at the Weymouth station $\left(50^{\circ} 37^{\prime}\right.$ N, $2^{\circ} 27^{\prime} \mathrm{W}$ ) since 1966 by the Centre for Environment, Fisheries \& Aquaculture Science (CEFAS) and focused on the period 1998-2012. The temperatures are recorded to at least an accuracy of $\pm 0.2^{\circ} \mathrm{C}$ (http://www.cefas.defra.gov.uk). As the L4 station is periodically affected by inputs of the Tamar estuary, we downloaded river discharge data from the Centre for Ecology \& Hydrology (http://www.ceh.ac.uk/data/nrfa).

\section{North-East Atlantic:}

The large-scale ARIVO (Analyse, Reconstruction et Indicateurs de la Variabilité Océanique: von Schuckman et al., 2009) gives gridded fields of temperature and salinity. Data are obtained by optimal analysis of in-situ observations, including ARGO observations but also data from CTD observations, drifting buoys and moorings. XBT and XCTDs are not included because of large uncertainties in the fall rate. Monthly fields of salinity and temperature are provided from 2002 to 2012 at the ARGO horizontal resolution (0.5 degree). 


\subsection{Large-scale hydro-climatic indices: teleconnection patterns and weather regimes}

Large-scale atmospheric variability is traditionally assessed by decomposing sea-level pressure anomalies into Empirical Orthogonal Functions (EOFs, Hurrell 1995) and the resulting modes of variability (or teleconnections) are associated with a spatial pattern and a time-series. In this study, we selected two large-scale hydro-climatic indices to examine their potential influence on the variability of Brest and Astan sites: the North Atlantic Oscillation (NAO, Hurrell 1995) and the East Atlantic Pattern (EAP, Barnston and Livezey 1987). We acknowledge that a large set of large-scale indices of climate forcing exists (Drinkwater et al. 2010) but we only focused here on indices known to significantly influence Western Europe (Hurrell 1995, Msadek and Frankignoul, 2009) and whose variability is consistent with our period of investigation.

The NAO characterizes the in-phase fluctuations of sea-level pressure anomalies between the Icelandic Low and the Azores High. Positive NAO conditions are characterized by strengthened midlatitude westerlies and trade winds and by a tripolar air-temperature anomaly pattern with warmer temperatures in the subtropics and Greenland-Iceland-Nordic Seas and colder temperatures in the Labrador Sea (Cayan, 1992). The EAP is defined by a center of action over $55^{\circ} \mathrm{N}$ and from $20^{\circ} \mathrm{W}$ to $35^{\circ} \mathrm{W}$. Its positive phase is characterized by cyclonic wind anomalies centered in the eastern North Atlantic (Barnston and Livezey, 1987). The EAP has a strong impact in Western Europe by influencing sea surface temperature (Goberville et al., 2013) or modulating mean precipitation rates and hydrological processes (Bojariu and Reverdin, 2002; Msadek and Frankignoul, 2009; Yang et al., 2005).

\section{Figure 2}

The spatio-temporal variability of these teleconnections is obtained by multiplying the time-varying index, with negative and positive values since time indices are most often centered on a mean of 0 , by the spatial pattern. However, while such decomposition assumes that the modes are symmetric, Cassou et al. (2004) demonstrated that this assumption does not hold for all teleconnections (e.g. the NAO, dominant mode of variability in the North Atlantic; Hurrell 1995) and argued for a non-linear consideration of the atmospheric variability to better characterize the effects of large-scale forcing. To overcome this 
limitation, an alternative is to decompose the large-scale atmospheric variability into weather regimes (WRs), which are recurrent, quasi-stationary large-scale atmospheric patterns (Cassou et al., 2011; Cassou et al., 2004; Michelangi et al., 1995; Vautard, 1990 among others). These WRs account for the existence of preferred large-scale spatial states of the extra tropical atmosphere set by the stationary waves (Molteni et al., 1990) and this framework allows to get rid of orthogonality and symmetry constraints peculiar to classical modes of variability (Cassou et al. 2004). Weather regimes are determined using daily mean sea level pressure (SLP) anomalies extracted from the NCEP reanalysis (http://www.esrl.noaa.gov/; Kalnay et al., 1996) from December 1957 to March 2012, following the methodology described in Barrier et al. (2012) and in annex C.

The four WRs we calculated (Fig. 2c-f \& Fig. 3) are similar to those depicted by Barrier et al. (2012). NAO+ (Fig. 2c \& 3a) and NAO- (Fig. 2e \& 3b) are the positive and negative phases of the NAO. The Scandinavian Blocking regime (BLK; Fig 2f) is characterized by (1) negative anomalies centered in Greenland and (2) positive anomalies centered in Northern Europe (Fig. 3c). The Atlantic Ridge (AR; Fig 2d) is characterized by anticyclonic anomalies centered in the eastern North-Atlantic and can be considered as a negative phase of the EAP (Fig. 3d). A detailed description of the surface forcing associated with these regimes is given by Barrier et al. (2013). Monthly correlation distances to WR were determined from 1979 to 2013 (Fig. 2c-f) using the WR patterns (Fig. 3) as follows: for each DJF month, the spatial correlations between the monthly mean SLP anomalies and the centroids (i.e. their climatological mean states, Fig. 3) were computed. Note that the WR indices can be interpreted as the degree of likeness between the monthly mean SLP anomalies and the centroids: a value of 1 indicates that the anomalies perfectly project onto the WR centroid, while a correlation of 0 indicates no similarity.

To compare the weather regime framework with the traditional decomposition in modes of variability (i.e. teleconnection indices), all the computations performed using the regime indices are also performed using the teleconnection indices provided by the NOAA (http://www.cpc.ncep.noaa.gov/ data/teledoc/telecontents.shtml)

\section{Figure 3}




\subsection{Correlation analysis}

The Pearson linear correlation coefficient was used to assess the relationships between the coastal to marine environment, regional precipitation, local river discharges, teleconnection indices and winter weather regimes. The coefficient of determination $\left(\mathrm{r}^{2}\right)$ was calculated from the coefficient of linear correlation (r) to measure how much of the variability of a given variable was explained by the other one (Legendre and Legendre, 1998). Probabilities were estimated and the Box and Jenkins (1976) autocorrelation function modified by Chatfield (1996) was used to assess the temporal dependence of years. When data were autocorrelated, the autocorrelation function was applied to adjust the degree of freedom and re-estimate the probability of significance using the Chelton's formula (1984) as applied by Pyper and Peterman (1998).

Trends of anomaly time series were estimated by applying the Spearman rank correlation permutation test (using 999 permutations with correction for multiple comparisons, Legendre \& Legendre, 1998; Table S1).

\section{Results and discussion:}

3.1. Time series of the two study sites $\left(48^{\circ} \mathrm{N}\right)$, compared to western channel sites $\left(50^{\circ} \mathrm{S}\right)$ and to the north-east Atlantic

3.1.1. Variability of the monthly mean of sea surface temperature, salinity and water discharge

\section{Figure 4}

Coastal waters in the Bay of Brest and at Roscoff-Astan showed typical seasonal variations in sea surface temperature (SST; Fig. 4a), salinity (SSS; Fig. 4b) and river discharge (Q; Fig. 4c; Data S1 in Annex A). The comparison between time series at the two sites (Fig. 4) revealed that: (1) the SST range was generally smaller at the Astan site than at 
the Brest site, with higher temperature during winter and lower temperature in summer (Fig. 4a); (2) the SSS range at the Astan site was much more restricted than at the Brest site, with the latter showing the predominant impact of rivers in the Bay of Brest (Fig. 4b); (3) the river run-off in the Bay of Brest (i.e. the Aulne+Elorn rivers) and in the Astan site (the Penzé River) were well in-phase (Fig. 4c).

\subsubsection{Bay of Brest site: high-frequency vs. low frequency sampling}

Temporal variations in the mean monthly SST calculated from the low-frequency SOMLIT-Brest time-series and from the high-frequency MAREL-Iroise time-series (Data S1 in Annex A) were synchronous over the period and therefore undistinguishable (Fig. 4a). In the same way, the mean monthly SSS for both SOMLIT-Brest and MAREL-Iroise varied in phase (Fig. 4b). Over the period, the mean difference between SSS from the SOMLIT data set and that monitored by MAREL was 0.13 pss. However, during flood events in the Bay of Brest, SOMLIT-Brest overestimated the mean salinity values (Fig. 4b). This phenomenon is related to the low-frequency data acquisition of the SOMLIT programme (i.e. monthly mean calculated from data measured once a week) compared to the MAREL high frequency data acquisition (i.e. monthly mean calculated from data measured three times per hour). Indeed, during flood events the peak of the river discharge of the Aulne and Elorn rivers impacted the salinity recorded by the MAREL-buoy after a few days; so one weekly measurement might have missed the accurate minimum SSS value. However, the monthly variability of both SST and SSS in the Bay of Brest was properly assessed by SOMLIT-Brest (Fig. 4a, b). The SOMLIT dataset can therefore be used to determine and quantify the potential influence of large-scale and local-scale processes on the variability of the physical and chemical characteristics of the coastal waters located at $48^{\circ} \mathrm{N}$.

\subsubsection{Extrema and means of SST and SSS at Brest and Astan sites}

At the Brest site, the mean monthly SST during the period 1998-2013 was minimal $\left(8.14^{\circ} \mathrm{C}\right)$ in February 2010 and maximal $\left(18.04^{\circ} \mathrm{C}\right)$ in August 2003. The mean monthly SSS was minimal (32.26 pss) in January 2001 and maximal (35.53 pss) in September 2003. At Astan, the mean monthly SST during the period $1998-2013$ was minimal $\left(8.65^{\circ} \mathrm{C}\right)$ in March 2010 and maximal $\left(16.53^{\circ} \mathrm{C}\right)$ in September 2009. The mean monthly SSS was minimal (34.27 pss) in February 2001 and maximal (35.49 pss) in December 2010. For each study site, 
average values in SST and SSS for (1) the period 1998-2013 and (2) only the winter months of the period are provided in Table 1. In winter, the salinity of coastal waters at both sites remained close to $35.5 \mathrm{pss}$, a typical mean value of the waters adjacent to the North Atlantic Ocean (e.g. Tréguer et al., 1979). These two systems can therefore be considered as coastal and not as estuarine systems.

\section{Table 1}

3.1.4. Variability of the monthly SST and SSS anomalies at the two study sites $\left(48^{\circ} \mathrm{N}\right)$, comparison with sites at $50^{\circ} \mathrm{N}$

\section{Figure 5}

The variability of monthly SST, SSS and river discharge anomalies at Astan (calculated by removing the 15-year monthly mean; Niu, 2013) was generally in phase with what we observed at Brest (Fig. 5a-c). The correlation between the variability of the monthly SST anomalies at Brest and Astan was significant ( $\mathrm{r}=0.743, \mathrm{p}<0.001)$ over the study period, as well as the variability between the monthly SSS anomalies at both sites $(r=0.710, p<0.001)$. The variability of the monthly river discharge anomalies of the Aulne+Elorn rivers was also significantly related to the Penzé River anomalies $(r=0.953, \mathrm{p}<0.001)$. These results suggest that similar large-scale and/or local-scale processes influenced the two systems during the period 1998-2013.

We compared the monthly variability in SST and SSS observed during the period from March 1998 to March 2013 at SOMLIT-Brest and SOMLIT-Astan with sampling carried out at two stations located at about $50^{\circ} \mathrm{N}$ in the Western English Channel (see Material and Methods). Significant correlations between the monthly SST anomalies in the coastal Weymouth station (data in Annex B) and SST anomalies calculated for SOMLIT-Brest $(r=0.627, p<0.001)$ and to lesser extent for Astan $(r=0.490, p<0.001)$ were found. Sea surface temperature recorded at the L4 station (data in Annex B) exhibited a high variability over the 
$20^{\text {th }}$ century, with several periods of warming and cooling (Smyth et al., 2010). Unfortunately, during our period of interest, the monitoring effort was perturbed and L4 was only regularly sampled from January 2002 to December 2012. During this period, the monthly SST anomalies at L4 were correlated with SOMLIT-Brest $(\mathrm{r}=0.600, \mathrm{p}<0.001)$ and SOMLIT-Astan $(\mathrm{r}=0.530, \mathrm{p}<0.001)$. The monthly SSS anomalies at L4 were also related with SOMLIT-Brest $(\mathrm{r}=0.447, \mathrm{p}<0.001)$, while the link with Astan was low although significant $(\mathrm{r}=0.278$, $\mathrm{p}=0.008$ ). This comparison suggests that similar processes influenced the variability of SST and SSS in both coastal waters off Brittany and the Western English Channel.

\subsubsection{Trends of SST and SSS over the 15-year study period}

We are aware that a 15-year study period is too short for establishing significant climatologic trends (e.g. Lorbacher et al., 2010). However, for comparative purposes, we calculated the trends of SST and SSS series from the anomaly time-series (Fig. 5a, b) for the two sites located in Western Brittany (at $48^{\circ} \mathrm{N}$ ) and for the period 1998 onwards. During this

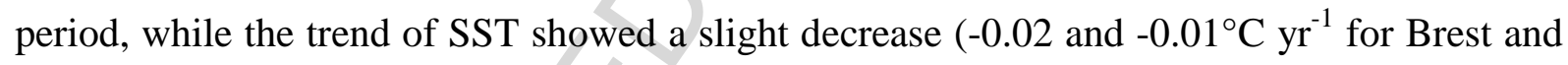
Astan, respectively; Fig. 5a), the trend of SSS exhibited a weak increase $(+0.02$ and +0.01 pss $\mathrm{yr}^{-1}$ for Brest and Astan, respectively; Fig. 5b) concomitant with the reduction in river discharges observed in both sites $\left(-0.6 \mathrm{~m}^{3} \mathrm{~s}^{-1}\right.$ per year for the Aulne+Elorn rivers and $-0.07 \mathrm{~m}^{3}$ $\mathrm{s}^{-1}$ per year for the Penzé River; Fig. $\left.5 \mathrm{c}\right)$.

These trends of SST and SSS were consistent with the trends calculated at a large scale from the ARIVO data set. By calculating the monthly SST and SSS anomalies for the period 2002-2012 (data before 2002 were unavailable) at the scale of Western Europe (from 40 to $60^{\circ} \mathrm{N}$ and from $10^{\circ} \mathrm{W}$ to $20^{\circ} \mathrm{E}$ ) the ARIVO data set exhibited a cooling trend in SST (region in pale blue; Fig. 6a) and a salinizing trend in SSS trend (region in pale yellow; Fig. 6b) in a domain close to the Brittany coasts.

\section{Figure 6}

To strengthen our finding of a reduction in SST over the monitored period, we analyzed the dataset ERSST_V3 provided by the National Oceanic and Atmospheric Administration 
(NOAA, http://www.esrl.noaa.gov/psd/) following the same procedure. This analysis also revealed a reduction in temperature (Fig. not shown), coincident with what we observed for both the sampled sites and the ARIVO dataset. While this current cooling has recently been corroborated at a planetary scale, including Western Europe (Kosaka and Xie, 2013), to our knowledge, no study has yet documented recent changes in SSS in our spatial domain.

We discerned a common pattern between the trends we calculated for our two study sites and the trends determined from both the ARIVO data set (for SST and SSS) and the NOAA data set (for SST). These results suggest that SOMLIT-Brest and SOMLIT-Astan reacted synchronously with what we observed at the scale of the Western Europe and confirm that trends in SST and SSS at these two coastal sites were, at least partly, driven by largescale processes (also see Goberville et al., 2010).

\section{3-2. Large-scale $v s$. local-scale processes impacting the variability of the characteristics of the coastal waters of Western Brittany during winter}

As shown in the previous section sea surface temperature and salinity in the two coastal systems, as well as the river discharges, which feed the coastal waters in freshwater and nutrients, varied at both seasonal and annual scales. Focusing on the winter period (i.e. December-January-February, DJF; DataS2 in Annex A), we address two questions: (1) Did large-scale processes influence the physical variability of coastal waters of the two study sites? (2) Did local-scale processes control the variability of physical and chemical (i.e. nutrients) characteristics of coastal waters? We distinguished the processes related to large and local-scale influences as follows (see Figure S4):

Large-scale processes: air masses circulate over the North Atlantic Ocean and exchange heat and water vapor with the surface ocean. Heat exchange between atmosphere and ocean plays a major role in warming or cooling the surface ocean waters, contributing to their temperature variations. Precipitation of atmospheric moisture on watersheds of Western Europe feeds tributaries of the coastal zone. The circulation of air masses and heat exchange between the atmosphere and the North Atlantic Ocean being determined by large-scale processes, correlations between sea surface temperature/rain rates on the watershed of our region and teleconnection patterns and/or weather regimes are expected. 
Local scale processes: abundant but variable precipitation during winter can also modulate river discharges, especially when subterranean reserves are small, as is the case with the Aulne River watershed (Mougin et al., 2008). Abundant but variable weathering of rocks and soils could also entrain labile nutrients such as nitrate. The chemical weathering of siliceous rocks of the watersheds by $\mathrm{CO}_{2}$ dissolved in rain water generates silicic acid in freshwater, which then discharges into the coastal zone through rivers and groundwater (Tréguer and De La Rocha, 2013).

\subsubsection{Did large-scale processes influence coastal waters of western Brittany $\left(48^{\circ} \mathrm{N}\right)$ during winter?}

\section{Influence of large-scale climate variability on sea surface temperature}

The variability of the winter (DJF) monthly SST in the SOMLIT-Brest and SOMLITAstan sites was compared to the variability of monthly teleconnection and weather regimes indices (Data S3 in Annex A). The mean seasonal cycle was removed to obtain anomalies and the DJF monthly anomalies were correlated with the DJF indices. The Table 2 shows significant correlations between monthly SST anomalies at the two study sites and (1) the North Atlantic Oscillation teleconnection index (NAO) and (2) both the NAO+ and NAOweather regime indices. No significant correlation was found with the East Atlantic Pattern (EAP), the Atlantic Ridge regime (AR) and the Scandinavian Blocking regime (BLK). During winter, large-scale processes have thus a palpable influence on sea surface temperature in the two coastal systems, the NAO index and the weather regimes linked to the NAO (the NAO+ and the NAO-) contributing from about 12 to $31 \%$ of the variability in SST (Table 2).

We also compared winter monthly SST and SSS anomalies calculated from the SOMLIT data set to gridded monthly anomalies calculated from the ARIVO database. Temperature anomalies in the North Atlantic sector were significantly correlated to SOMLITBrest (ranging from 0.4 to 0.5 ; Fig. S1a) and, to a lesser extent, to SOMLIT-Astan (ranging from 0.2 to 0.3 ; Fig. S1b), exhibiting a large-scale oceanic influence on sea surface temperature in both sites. No highly significant correlation was found with salinity at either site (Fig. S2; Table S2). High correlations detected for SST compared to weak correlations for SSS could be induced by the prevalence of local-scale processes on salinity, as discussed later (see 3.2.2). 


\section{Table 2}

\section{Influence of large-scale variability on precipitation anomalies}

In this section, we investigated the potential relationships between precipitation and large-scale patterns assessed by means of teleconnections (TPs) and weather regimes (WRs). To do so, we used monthly precipitation provided by the Global Precipitation Climatology Project (GPCP) version 2.2 (http://www.gewex.org/gpcp.html; Adler et al., 2003) for the period 1979-2013 and examined the spatial patterns of correlation between each of the six indices (see Fig. 2) and winter monthly precipitation anomalies. Results from correlations analysis for the time-period ranging from Jan. 1979 to Dec. 2013 are shown in Fig. 7.

The results obtained with the TP and the WR indices (NAO/NAO+, NAO/NAO-, EAP/AR) were consistent. In accordance with Hurrell (1995), Hurrell and Van Loon (1997) and Marshall et al. (2001), the NAO predominantly influenced precipitation in Europe (Fig. 7a). The positive phase of the NAO was characterized by enhanced precipitation in Northern Europe and decreased precipitation in Southern Europe (Fig. 7c). These anomalies are related to changes in moisture transport driven by NAO-induced wind-anomalies (Hurrell, 1995). In the WR framework, the anomalies for the NAO+ and the NAO- (Fig. 7c, e) were comparable but located further north for the NAO-. The Scandinavian BLK was characterized by reduced precipitation in central Europe and increased precipitation in the Greenland, Iceland, and Norwegian seas (Fig. 7f). These anomalies are probably the result of the persistent anticyclone centered in Europe which prevents moist air from penetrating inland, hence leading to a northward shift of this moist air. The EAP/AR correlation maps (Fig. 7b, d) showed a similar but opposite pattern of influence (the sign of the EAP being inverted) in both western France and Great Britain (Plaut and Simonnet, 2001; Wibig, 1999). While we observed a reduction in precipitation in association with the AR (Fig. 7d), the EAP correlation map displayed an increase in precipitation in these regions (Fig. 7b). These anomalies are the consequence of the anticyclonic wind anomalies and the resulting dominant Northwest flow in Western Europe under AR/EAP- conditions. The correlation maps we calculated (Fig. 7) are consistent with the patterns discussed by Bojariu and Reverdin (2002). 


\section{Figure 8}

The analysis of the GPCP data set displayed a general pattern of the relationships between precipitation anomalies and the large-scale variability in the North-Atlantic/Europe domain. However, the coarse resolution of the data set $\left(2.5^{\circ}\right)$ does not allow unequivocal regional conclusions. Indeed, it is difficult to determine the regime that predominantly influences the variability of precipitation in Brittany (Fig. 7). To refine the approach, similar correlations analyses were performed using monthly precipitation monitored at a meteorological station representative of the local variability in rain rates (in Guipavas; $48^{\circ} 44^{\prime}$ $\mathrm{N}, 4^{\circ} 41^{\prime} \mathrm{W}$; Data $\mathrm{S} 4$ in Annex A). Our results show that the rain rate anomalies from February 1998 to February 2013 were highly positively correlated with the East Atlantic Pattern ( $\mathrm{r}=0.673, \mathrm{p}<0.001$; Table 3$)$ and negatively with the Atlantic Ridge $(\mathrm{r}=0.485$, $\mathrm{p}=0.001$; Table 3 ), revealing the influence of large-scale processes on local precipitation during winter. No relationship was found with the North Atlantic Oscillation (Table 3).

Our results are consistent with the idea that, on a monthly basis, the SST variability could be linked to the heat exchange between atmosphere and ocean (e.g. Hansen et al. 2006; Harley et al. 2006). In contrast, the precipitation variability appears to be more related to atmospheric processes (Goberville et al. 2010; Harley et al. 2006; New et al. 2001).

\section{Table 3}

\subsubsection{Did local-scale processes influence the physical and chemical characteristics of coastal waters of western Brittany during winter?}

Weathering of the rocks and soils of the watersheds by precipitation feeds rivers with freshwater that is rich in nitrate and silicic acid (e.g. Delmas and Tréguer, 1983; Le Jehan and 
Tréguer, 1984). Local-scale processes are therefore expected to impact the physical and chemical characteristics of coastal waters.

\section{Influence of precipitation on river discharges}

During winter, we assume that both direct evaporation and evapo-transpiration (via terrestrial plants) are unimportant processes compared to precipitation. Because the watersheds upstream of our two study sites are mainly composed of both impermeable rocks and soils (i.e. layers through which water cannot pass), most of the precipitation is directly and rapidly entrained through rivers. River discharges should be reactive to the variations in rain rates (e.g. Ludwig et al. 2009).

The combination of the Aulne and Elorn river outflows contributes to $85 \%$ of the total river discharge to the Bay of Brest (Delmas and Tréguer, 1983), the Aulne river discharge predominating that of the Elorn by a factor of 4.55. Note that, in opposition to the Aulne, larger underground reserves exist for the Elorn watershed (Mougin et al., 2008). These reserves might delay, at least partly, the response of the riverine system to precipitation forcing. We recall that the total freshwater inputs for the Brest site were estimated by summing the discharges of the Aulne and the Elorn rivers. For the Roscoff coastal system, the Penzé discharge was used to evaluate the total river discharge. Using the rain rate recorded at the Guipavas Meteo-France station as a proxy, the river discharges were expected to be related to the precipitation delivered to the watershed (Data S5 in Annex A).

\section{Table 4}

Rain rate anomalies monitored during the period 1998-2013 at Guipavas were highly related to winter monthly river discharge anomalies of the Aulne+Elorn rivers $(\mathrm{r}=0.762,58 \%$ of the explained variability; Table 3 ) and anomalies of the Penzé River ( $r=0.610,37 \%$ of the explained variability; Table 3) displaying that the temporal variability of precipitation had a patent influence on the variability of the stream flow in the two study sites. 
The need to better understand and quantify large-scale climate forcing on local river discharge has drawn much attention during the last decades (Barlow et al., 2001; Giuntoli et al. 2013; Milliman et al. 2008; New et al., 2001). Large-scale climate-induced changes have been extensively documented and have triggered reflections on the aim to project potential flood and/or drought events, for the local authorities to better manage the socioeconomic impacts of rapid changes in stream flow (IPCC, 2013). However, from the point of view of "process studies" such as ours, we emphasize here that the correlative link between largescale variability and river discharge is modulated via two coupled processes: river discharge generally reflected precipitation rates, themselves influenced by large-scale atmospheric/oceanic patterns (e.g. New et al., 2001; Milliman et al. 2008). Therefore, it is not surprising that correlation coefficients between the variability of river discharges and largescale indices were lower than those calculated between the variability of rain rates and largescale patterns.

In our study area, river discharges were positively correlated with the EAP index $(\mathrm{r}=0.594, \mathrm{p}<0.001$ for the Aulne+Elorn and $\mathrm{r}=0.478, \mathrm{p}<0.001$ for the Penzé; Table 2) and negatively related to the Scandinavian BLK regime ( $r=-0.383, \mathrm{p}=0.012$ for the Aulne+Elorn and $r=-0.406, p=0.007$ for the Penzé; Table 2). While we observed a clear influence of the AR on precipitation anomalies (Table 2), no significant correlation was found with the Penzé river discharge ( $\mathrm{r}=-0.207, \mathrm{p}=0.189$; Table 2) and only a weak relation was found with the Aulne+Elorn river discharge $(\mathrm{r}=-0.307, \mathrm{p}=0.048$; Table 2). The Atlantic Ridge and the East Atlantic Pattern showing a similar (but opposite) spatial pattern of correlation in the Armorican peninsula (Fig. 7b, d), the influence of these indices on the Aulne+Elorn and the Penzé river discharges was expected to be congruent. As shown by our correlation analysis, this assumption was not confirmed, river discharges being mainly related to the EAP and the BLK with only a weak influence of the AR. This contrasting result could be explained by the fact that, compared with the Atlantic Ridge regime, the BLK regime has a greater influence on precipitations on the eastern part of our region where the sources of the Aulne and the Elorn rivers are located (Fig. 1). This result highlights the relevance of considering both TPs and WRs indices for an accurate assessment of the large-scale processes influencing the variability of the environment.

Influence of local rivers on salinity of coastal waters 
As we described, coastal waters of both study sites are marine waters with freshwater inputs being greatest during winter. Monthly SSS anomalies at SOMLIT-Brest and at SOMLIT-Astan were correlated to river discharge anomalies (Table 3; Data S5 in Annex A). Our results exhibited that fluctuations of inputs from the two major tributaries of the Bay of Brest (Aulne+Elorn) explained about $50 \%$ of the variation of salinity of the coastal waters $(\mathrm{r}=-0.706, \mathrm{p}<0.001$; Table 4). At the Roscoff site, more than $24 \%$ of the variation of salinity was explained by the influence of the Penzé River ( $r=-0.507, p=0.002$; Table 3).

Additional processes also influence the salinity of the coastal waters. First, as we mentioned in the introduction section, SSS in our domain of interest varies in relation with the salinity of the eastern border current of the North Atlantic. Second, at a regional scale, it has been shown that the discharge of the Vilaine (river mouth at about $47^{\circ} 30^{\prime} \mathrm{N}$; mean annual discharge $71 \mathrm{~m}^{3} \mathrm{~s}^{-1}$, winter maximum $500 \mathrm{~m}^{3} \mathrm{~s}^{-1}$ ) and of the Loire (river mouth at about $47^{\circ} \mathrm{N}$; mean annual discharge $900 \mathrm{~m}^{3} \mathrm{~s}^{-1}$; winter maximum $1830 \mathrm{~m}^{3} \mathrm{~s}^{-1}$ ) could influence the salinity (and therefore the nutrient concentrations) of coastal waters of the Bay of Brest and off Roscoff (Dussauze and Menesguen, 2008). Indeed, when the stream outflow penetrates into the Atlantic Ocean, it is deviated to the north by the Coriolis force. This could potentially impact the hydrological and chemical characteristics of the coastal waters of the southern, the western and even of the northern Brittany, especially during floods (and to a large extent during winter and spring).

Influence of local rivers on nutrient concentrations in coastal waters of the Bay of Brest

Our results provide evidence that the discharge of local rivers affects SSS at the outlet of the Bay of Brest. The concentration of labile nutrients such as nitrate and silicic acid is also impacted and nutrients are transported by the rivers to the Bay of Brest. This is illustrated herein for the salinity minimum events which occurred during winter (Fig. 4b). During winter floods of the Aulne River, the transit time of freshwater through the Bay of Brest is only a few days. With such a short time we made the assumption that the transport of nutrients through the estuaries and the bay was conservative (i.e. a distribution of nutrients influenced only by physical mixing or turbulent diffusion processes and not by biological processes). By selecting seasonal salinity minimum events of the SOMLIT-Brest 1998-2013 time series (Data S6 in Annex A) we represented the variations of both nitrate and silicic acid concentration vs. salinity (Fig. 8). Note that, for all the selected samples but one, the 
chlorophyll- $a$ concentration was $<1 \mu \mathrm{g} \mathrm{L}{ }^{-1}$, i.e. far below typical spring bloom values (Data S6 in Annex A).

\section{Figure 9}

Figure 8 illustrates the linear regression between nitrate or silicic concentrations (in ordinate) and salinity (in abscissa) at SOMLIT-Brest, considering only the salinity minimum events. The correlations were significant $(r=0.890, p<0.001$ for nitrate and $r=0.877, p<0.001$ for silicic acid), supporting our conservative hypothesis. If this hypothesis is correct, the intercept of the y-axis of the mixing diagram (Fig. 8) should correspond to the average concentrations of nitrate or silicic acid in the freshwater end-member (FEM) of the freshwater-marine water mixture. The composition of the FEM results from a mixture of the Aulne and the Elorn freshwater and the nutrient concentration of the FEM was calculated assuming that the ratio of the Aulne discharge to that of the Elorn was 4.55 times more important in winter (Table 4). The nitrate and silicic acid average concentrations and ranges, for the Aulne and the Elorn during winter were calculated from the ECOFLUX time series.

\section{Table 6}

The difference between the mean concentration observed at the y-axis intercept and the rebuilt FEM mean concentration is insignificant for nitrate. This result is in agreement with our hypothesis of a conservative distribution of nitrate through the Bay of Brest in winter ( $<1 \%$; Table 4). The silicic acid mean concentration in the FEM shows an apparent deficit of about 16\% (Table 4). However, reverse weathering (geochemical consumption of silicic acid to build more siliceous material in sediments) is a well-known process of the silica cycle within estuaries (Tréguer and De La Rocha, 2013). If it occurs, this negative anomaly does not correspond to biological uptake and thus does not contradict our conservative hypothesis. Dussauze et al. (2011) showed that in addition to local rivers the Loire River might also impact the composition of the Bay of Brest waters. However, during the salinity minimum events of our study period the contribution of the Loire River to the nutrient composition of 
the Bay of Brest was negligible (about 0.8\%; Dussauze et al., 2011). As the transit time between the Loire River mouth and the Bay of Brest is about 2-3 months (Dussauze 2013, personal communication) and owing to the unknown fate of nitrate or silicic acid during this transit, it is difficult to correct the composition of the FEM taking into account the nutrient contribution from the Loire River.

\section{Conclusions}

Both large-scale and local-scale processes impact the variability of physical and chemical characteristics of the coastal waters of Western Europe during winter.

The variability of SST reflects, at least partly, variations in heat exchanges between the ocean and the atmosphere in association with the NAO index, that of SSS being mainly related to the EAP. The convergent conclusions we reached by using either the teleconnection patterns (NAO, EAP) or the weather regimes (NAO+, NAO-, AR, BLK) make our conclusions more robust. Because of the potential spatial asymmetry of large-scale patterns and the resulting consequences on both the amplitude and location of these forcing, such an approach should be recommended in further studies for a more accurate estimation of the large-scale processes that influence natural systems.

At a local scale, the variability of the small river discharges in the coastal zone is mainly explained by the weathering of impermeable soils and rocks by precipitation. Our study shows that during winter, the dominance of a positive EAP phase could support an increase in precipitation and therefore, through river discharges, the delivery of high nutrient standing stocks to the coastal waters of Western Europe, leading to a high new production during the following spring.

Acknowledgements: Thanks are due to an anonymous reviewer for useful comments. The authors are grateful to Julien Boe and Christophe Cassou (Cerfacs, Toulouse), to Bernard Le Cann (LPO, IUEM-UBO-Ifremer, Brest), and to David M. Nelson (UBO, OSU) for fruitful exchanges and its help in editing the revised version of the manuscript. Thanks are due to IFREMER for funding the MAREL-Iroise Programme and to the Conseil Genéral du Finistère 
which supports the ECOFLUX Programme. This is a contribution to the INSU-CNRS funded SOMLIT Programme.

\section{Data and supplementary information}

Data used in this study (Annex A : $48^{\circ} \mathrm{N}$; Annex B $50^{\circ} \mathrm{N}$ ); details of calculations related to winter regimes (Annex $\mathrm{C}$ ) and supplementary information to this article can be found on line at: https://filex.univ-brest.fr/get?k=O8NvDXGtuvvDEEcu9Jj

\section{References}

Adler, R., Huffman, G.J., Chang, A., Ferraro, R., Xie, P.-P., Janoviak, J., Rudolf, B., Schneider, U., Curtis, D., Gruber, A., Arkin, P., Nelkin, E., 2003. The version-2 global precipitation climatology project (GPCP) monthly precipitation analysis (1979-present). J. Hydrometeor. 4, 1147-1167.

Aminot, A., Kerouel, R., 2007. Dosage automatique des nutriments dans les eaux marines: méthodes en flux continu. Méthodes d'analyses en milieu marin. Editions Ifremer, Paris, $250 \mathrm{pp}$.

Arhan, M, Colin de Verdière, A, Mémery L., 1994. The eastern boundary current of the subtropical North Atlantic. J. Phys. Oceanogr.24, 1295-1316.

Barlow, M., Nigam, S., Berbery, E.H., 2001. ENSO, Pacific decadal variability, and U.S. summertime precipitation, drought, and stream flow. J. Climate 14, 2105-2128.

Barnston, A., Livezey, R.E., 1987. Classification, seasonality and persistence of lowfrequency atmospheric circulation patterns. Mon. Weather. Rev. 115, 1083-1126.

Barrier, N., Treguier, A.-M., Cassou, C., Deshayes, J., 2012. Impact of the winter northatlantic weather regimes on subtropical sea-surface height variability. Clim. Dynam. 41, 1159-1171.

Barrier, N., Treguier, A.-M., Cassou, C., Deshayes, J., 2013. Response of north-atlantic ocean circulation to atmospheric weather regimes. J. Phys. Oceanogr. (in press). http://dx.doi.org/10.1175/JPO-D-12-0217.1.

Beucher, C, Tréguer, P, Corvaisier, R, Hapette, AM, Elskens, M., 2004. Production and dissolution of biogenic silica, and changing microphytoplankton dominance in the Bay of Brest (France). Mar. Ecol. Prog. Ser. 267, 57-69. 
Bojarriu, R., Reverdin, G., 2002. Large-scale variability modes of freshwater flux and precipitaion over the Atlantic. Clim. Dynam. 18, 369-381.

Box, G.E.P., Jenkins, G.W., 1976. Time Series Analysis: Forecasting and Control. HoldenDay, San Francisco, CA.

Breton, E., Rousseau V, Parent, J.Y., Ozer J, Lancelot C., 2006. Hydroclimatic modulation of diatoms/Phaeocystis blooms in nutrient-enriched Belgian coastal waters (North Sea). Limnol. Oceanogr. 51, 1401-1409.

Cassou, C., Terray, L., Hurrell, J., Deser, C., 2004. North Atlantic winter climate regimes: Spatial asymmetry, stationarity with time, and oceanic forcing. J. Climate 17, 10551068.

Cassou, C., Minvielle, M., Terray, L., Perigaud, C., 2011. A statistical-dynamical scheme for reconstructing ocean forcing in the Atlantic. Part I: weather regimes as predictors for ocean surface variables. Clim. Dynam. 36, 19-39.

Cayan, D., 1992. Latent and sensible heat-fluxes anomalies over the Northern Oceans Driving the Sea-Surface Temperature. J. Climate 5, 354-369.

Chatfield, C., 1996. The Analysis of Time series: An Introduction. Chapman and Hall, London.

Chelton, D.B., 1984. Commentary: short-term climatic variability in the northeast Pacific Ocean. In: Pearcy, W. (Ed.), The influence of ocean conditions on the production of salmonids in the North Pacific. OregonStateUniversity Press, Corvallis, OR, pp. 87-99.

Costanza, R., D'arge, R., De Groot, R., Farber, S., Grasso, M., Hannon, B., Limburg, K., Naeem, S., O'Neill, R.V., Paruelo, J., Raskin, R.G., Sutton, P., van den Belt, M., 1997. The value of the world's ecosystem services and natural capital. Nature, 387, 253-260.

Del Almo, Y., Quéguiner, B., Tréguer, P., Breton, H., Lampert, L., 1997. The impacts of high-nitrate freshwater inputs in macrotidal ecosystems: II- The specific role of the "silicate pump" in the year-round dominance of diatoms in the Bay of Brest (France). Mar. Ecol. Prog. Ser. 161, 225-237.

Delmas, R., Tréguer, P., 1983. Evolution saisonnière des matières nutritives dissoutes dans un écosystème eutrophe d'Europe occidentale. Oceanol. Acta 6, 345-356.

Diaz, R., Rosenberg, R., 1995. Marine benthic hypoxia: A review of its ecological effects and the behavioural responses of benthic macrofauna. Oceanogr. Mar. Biol. An. Rev. 33, 245-203. 
Dürr, H.H., Laruelle, G.G., van Kempen, C.M., Slomp, C.P., Meybeck, M., Middelkoop, H., 2011. Worldwide typology of nearshore filter of river inputs to the oceans. Estuar. Coast. 34, 441-448.

Dussauze, M., Menesguen, A., 2008. Simulation de l'effet sur l'eutrophisation côtière bretonne de 3 scénarios de réduction des teneurs en nitrate et phosphate de chaque bassin versant breton et de la Loire. Rapport Ifremer pour la Région Bretagne et l'Agence de l'Eau Loire-Bretagne, 160 p.

Dussauze, M., Menesguen, A., Dumas, F., 2013. Use of passive and active tracers in the biogeochemical-3D hydrodynamical ECO-MARS3D model to assess the role of river inputs on coastal zone of France, British Channel and southern North Sea. Traces and tracers colloquium, Liège, Belgium 2-6 May 2011.

Garaglia, F., Gailhard, J., Paquet, E., Lang, E., Garçon, R., Bernardara, P., 2010. Introducing a rainfall compound distribution model based on weather patterns sub-sampling. Hydrol. Earth Syst. Sc. 14, 951-964.

Giuntoli, I., Renard, B., Vidal, J.P., Bard, A., 2013. Low flows and their relationship to large climate indices. J. Hydrol. 482, 105-118.

Goberville, E., Beaugrand, G., Edwards, M., 2013. Synchronous response of marine plankton ecosystems to climate in the Northeast Atlantic and the North Sea. J. Marine Syst. 129, 189-202.

Goberville, E., Beaugrand, G., Sautour, B., Tréguer, P., 2010. Climate-driven changes in coastal marine systems of Western Europe. Mar. Ecol. Prog. Ser. 408, 129-147.

Häkkinen, S., Rhinds, P.B., Worthen, D.L., 2011. Atmospheric blocking and Atlantic multidecadal ocean variability. Science 334, 655-659.

Hansen, J., Sato, M., Ruedy, R., Lo, K., Lea, D.W., Medina-Elizade, M., 2006. Global temperature change. Proc. Natl. Acad. Sci. USA, 103, 14288-14293.

Harley, C.D.G., Hughes, A.R., Hultgren, K.M., Miner L.F., Tomanek, L., Sorte C.J.B., Thomber, C.S., Rodriguez, , B.G., .Williams, S.L., 2006. The impacts of climate change in coastal marine systems. Ecol. Lett.9, 228-241.

Hurrell, J. W., Van Loon, H., 1997. Decadal variations in climate associated with the North Atlantic Oscillation. Clim. Change 36, 301-326.

Hurrell, J., 1995. Decadal trends in the North Atlantic Oscillation: regional temperatures and precipitations. Science 269, 676-679.

Hurrell, J.W., Kushnir, Y., Visbeck, M., Ottersen, G., 2003. An overview of the North Atlantic Oscillation, in The North Atlantic Oscillation: Climatic Significance and 
Environmental Impact, Geophys. Mono gr. Ser., vol. 134, edited by J. W. Hurrell et al., pp. 1-35, AGU, Washington, DC.

Intergovernmental Panel on Climate Change (IPCC), 2013. Climate Change 2013: The Physical Science Basis. Cambridge University Press, Cambridge.

Kalnay, E., Kanamitsu, M., Kistler, R., Collins, W., Deaven, D., Gandin, L., Iredell, M., Saha, S., White, G., Woollen, J., Zhu, Y., Leetmaa, A., Reynolds, R., Chelliah, M., Ebisuzaki, W., Higgins; W., Janowiak, J., Mo, K.C., Ropelewski, C., Wang, J., Jenne, R., Joseph, D., 1996. The NCEP/NCAR 40-year reanalysis project. Bull. Am. Meteorol. Soc. 77, 437-471.

Kosaka, Y., Xie, S.-P., 2013. Recent global-warming hiatus tied to equatorial Pacific surface cooling. Nature 501, 403-407.

Labat, D., Godd, Y., Probst, J.L., Guyot, J.L., 2004. Evidence for global runoff increase related to climate warming. Adv. Water Res. 27, 631-642.

Legendre, P., Legendre, L., 1998. Numerical Ecology, $2^{\text {nd }}$ edn. Elsevier Science BV, Amsterdam.

Le Jehan, S., Tréguer, P., 1984. Evolution saisonnière de composés organiques dissous dans un écosystème eutrophe d'Europe occidentale (rade de Brest). Oceanol. Acta 7, 181189.

Le Tissier, M.D.A., Buddemeier, R., Parslow, J., Swaney, D.P. Crossland, C.J., Smith, S.V., Whyte, H.A.Y, Dennison, W.C, Hills, J.M., Kremer, H.H., 2006. The role of the coastal ocean in the disturbed and undisturbed nutrient and carbon cycles-a management perspective. Land-Ocean Interactions in the Coastal Zone (LOICZ), Geesthacht.

Ludwig, W., Dumont, E., Meybeck, M., Heussner, S., 2009. River discharges of water and nutrients to the Mediterranean and Black Sea: Major drivers for ecosystem changes during past and future decades? Prog. Oceanogr. 80, 199-217.

Lorbacher, K., Dengg, J., Böning, C.W., Biastoch, A., 2010. Regional patterns of sea level change related to interannual variability and multidecadal trends in the Atlantic Meridional overturning circulation. J. Climate 23, 4243-4254.

Marshall, J., Kushnir, Y., Battisti, D., Chang, P., Czaja, A., Dickson, R., Hurrell, J., McCartney, M., Saravanan, R., Visbeck, M., 2001. North Atlantic climate variability: phenomena, impacts and mechanisms. Int. J. Climatol. 21, 1863-1898.

Meybeck, M., Dürr H.H., Vörösmarty C.J., 2006. Global coastal segmentation and its river catchment contributors: a new look at land-ocean linkage. Global Biogeochem. Cy. 20, GBS90. 
Michelangi, P., Vautard, R., Legras, B., 1995. Weather regimes: Recurrence and quasi stationarity. J. Atmos. Sci. 52, 1237-1256.

Milliman, J.D., Farnsworth, K.L., Jones, P.D., Xu, K.H., Smith, L.C., 2008. Climatic and anthropogenic factors affecting river discharge to the global ocean, 1951-2000. Global Planet. Change 62, 187-194.

Molteni, F., Tibaldi, S., Palmer, T., 1990. Regimes in the wintertime circulation over northern extratropics. I: Observational evidence. Q. J. Roy. Meteor. Soc. 116, 31-67.

Mougin, B., Allier, D., Blanchin, R., Carn, A., Courtois, N., Gateau, C., Putot, E., 2008. SILURES Bretagne - Rapport final - Année 5. BRGM/RP 56457-FR, 129 pp.

Msadek,R., Frankignoul, C., 2009. Atlantic multidecadal variability and its influence on the atmosphere in a climate model. Clim. Dyn. 33, 45-62.

New, M., Todd, M., Hulme, M., Jones, P., 2001. Precipitation measurements and trends in the twentieth century. Int. J. Climatol. 21, 1889-1922.

Niu, J., 2012. Precipitation in the Pearl River basin, South China: scaling, regional patterns, and influence of large-scale climate anomalies. Stoch. Environ. Res. Risk. Assess. 27, $1253-1268$

Peters, D.P.C., Bestelmeyer B.T., Turner M.G., 2007. Cross-scale interactions and changing pattern process relationships: consequences for system dynamics. Ecosystems 10, 790796.

Pyper, B.J., Peterman, R.M., 1998. Comparison of methods to account for autocorrelation analyses of fish data. Can. J. Fish. Aquat. Sci. 55, 2127-2140.

Quéguiner, B., Tréguer, P., 1984. Studies on the phytoplankton in the Bay of Brest (Western Europe), seasonal variations in composition, biomass nad production in relation to hydrological and chemical features (1981-1982). Bot. Mar. 27, 449-459.

Rogers,J.C., 1997. North Atlantic storm track variability and its association to the North Atlantic Oscillation and climate variability of northern Europe. J. Climate 10, 16351647.

Seager, R., Battisti, D.S., Yin, J., Gordon, N., Naik, N., Clement, A.C., Cane, M.A., 2002. Is the Gulf Stream responsible for Europe's mild winters? Q. J. Roy. Meteor. Soc. 128, 2583-2586.

Selman, M., Greenhalgh, S., Diaz, R., Sugg, Z., 2008. Eutrophication and hypoxia in coastal areas: a global assessment of the state of knowledge. Water Quality: Eutrophication and Hypoxia, 1. 
Smyth, T.J., Fishwick, J.R., Al-Moosawi, L., Cummings, D.G., Harris, C., Kitidis, V., Rees, A., Matrinez-Vicente, V., Woodward, E.M.S., 2010. A broad spatio-temporal view of the Western English Channel observatory. J. Plankton Res. 32, 585-601.

Tréguer, P., De La Rocha, C.J., 2013. The world ocean silica cycle. Annu. Rev. Mar. Sci. 5, 477-501.

Tréguer, P., Le Corre, P., Grall, J.R., 1979. The seasonal variations of nutrients in the upper waters of the Bay of Biscay region and their relation of phytoplankton growth. DeepSea Res. 26, 1121-1152.

Tréguer P., Le Corre P., 1975. Analyse automatique des sels nutritifs: utilisation de l'AutoAnalyzer II, UBO, $150 \mathrm{pp}$.

Vautard, R., 1990. Multiple weather regimes over the North-Atlantic. Analysis of precursors and successors. Mon. Weather Rev. 118, 2056-2081.

Von Schuckmann, K., Gaillard, F., Le Traon. P.-Y., 2009. Global hydrographic variability patterns during 2003-2008. J. Geophys. Res. 114, 1-17.

Yang, C., Chandler, R.E., Isham, V.S., Wheater, H.S., 2005. Spatial-temporal rainfall simulation using generalized linear models, Water Resour. Res. 41, W11415.

Wibig, J., 1999. Precipitation in Europe in relation to circulation patterns at the $500 \mathrm{hPa}$ level. Int. J. Climatol. 19, 253-269. 


\section{Figure Legends}

Fig. 1. Map of the study area and position of the sampling sites. The insert shows the location of the site in Western Europe. Black spots: SOMLIT-Brest and Marel-Iroise sites (at the outlet of the Bay of Brest), SOMLIT-Astan site (off Roscoff, at the outlet of the Bay of Morlaix) and Meteo-France station (in Guipavas). Black stars: gauging stations of ECOFLUX (the Aulne, the Elorn and the Penzé rivers). The watersheds of the rivers are in blue. Insert: location of the two stations ("L4" and "Weymouth") in the north western English Channel.

Fig. 2. (a-b) Large-scale climate indices and (c-f) weather regime indices calculated for the winter months (DJF) and from 1979 to 2012. Positive anomalies are in red and negative in blue. Winter weather regime indices were determined from the winter weather regime patterns (see Material and Methods). The red dotted line marks the beginning of our study period (i.e. 1998). (a) NAO: the North Atlantic Oscillation; (b) EAP: the East Atlantic Pattern ; (c) NAO+: positive phase of the NAO ; (d) AR: the Atlantic Ridge ; (e) NAO-: negative phase of the NAO ; (f) BLK: the Scandinavian Blocking regime. The East Atlantic Pattern was inverted (multiplied by -1 ) for comparison with the Atlantic Ridge.

Fig. 3. Spatial representation of the centroids of the four winter weather regime patterns used to calculate the weather regime indices (see Material \& Methods). (a) NAO+: positive phase of the NAO; (b) NAO": negative phase of the NAO; (c) BLK: the Scandinavian Blocking regime; (d) AR: the Atlantic Ridge. Color shading: Sea level pressure anomalies derived centroids (contour interval: $200 \mathrm{~Pa}$ ).

Fig. 4. (a) Monthly mean sea surface temperature (SST; in ${ }^{\circ} \mathrm{C}$ ) and (b) sea surface salinity (SSS; in pss) at the MAREL-Iroise (blue), SOMLIT-Brest (red) and SOMLIT-Astan (black) sites. (c) Monthly mean river discharge (Q; in $\left.\mathrm{m}^{3} \mathrm{~s}^{-1}\right)$ of the Aulne+Elorn (red) and the Penzé (black) rivers. For a visual comparison, the Penzé river discharge was multiplied by 10.

Fig. 5. (a) Monthly mean sea surface temperature (SST; in ${ }^{\circ} \mathrm{C}$ ) anomalies and (b) sea surface salinity (SSS ; in pss) anomalies at the SOMLIT-Brest (red) and SOMLIT-Astan (black) sites. (c) Monthly mean river discharge $\left(\mathrm{Q}\right.$; in $\left.\mathrm{m}^{3} \mathrm{~s}^{-1}\right)$ anomalies of the Aulne+Elorn (red) and the Penzé (black) rivers. For a visual comparison, the anomalies of the discharge of the Penzé 
were multiplied by 10 . The dotted lines correspond to the trends of each time series (See Table S1).

Fig. 6. Trends in (a) sea surface temperature (in ${ }^{\circ} \mathrm{C} / \mathrm{decade}$ ) and (b) sea surface salinity (in pss/decade) calculated for the period 2002-2012 in the domain ranging from $40^{\circ} \mathrm{N}$ to $60^{\circ} \mathrm{N}$ and from $10^{\circ} \mathrm{W}$ to $20^{\circ} \mathrm{E}$ (calculated from the ARIVO data set; from von Schuckmann et al., 2009).

Fig. 7. Correlation maps between DJF (December-January-February) monthly mean precipitation anomalies and DJF monthly mean large-scale indices. (a) NAO: the North Atlantic Oscillation; (b) EAP: the East Atlantic Pattern; (c) NAO+: positive phase of the NAO; (d) AR: the Atlantic Ridge; (e) NAO-: negative phase of the NAO; (f) BLK: the Scandinavian Blocking regime. The East Atlantic Pattern was inverted (multiplied by -1) for comparison with the Atlantic Ridge. The color shading shows the correlation values. Black dots indicate the areas where correlations are significant after correction to account for temporal autocorrelation.

Fig. 8. Linear regressions between surface nitrate $\left(\mathrm{NO}_{3}\right.$; in red) and silicic acid $\left(\mathrm{Si}(\mathrm{OH})_{4}\right.$; in blue) concentrations (in $\mu \mathrm{M}$ ), and sea surface salinity (in pss) for the winter months (December-January-February) of the period 1998-2013 (SOMLIT-Brest). Surface nutrient concentrations are in ordinates. Sea surface salinity, determined at salinity minimum events (see Fig. 4b and Table S4), is in abscissa. Regression lines: $\left[\mathrm{NO}_{3}\right]=-12.304 \mathrm{x}$ salinity + 438.36 and $\left[\mathrm{Si}(\mathrm{OH})_{4}\right]=-3.3071 \times$ salinity +121.72 . 


\section{Table Legends}

Table 1. $48^{\circ} \mathrm{N}$ (SOMLIT-Brest, SOMLIT-Astan, and MAREL) and $50^{\circ} \mathrm{N}$ (Plymouth L4 and Weymouth) stations: mean values (and standard deviations) of sea surface temperature (SST; in ${ }^{\circ} \mathrm{C}$ ) and sea surface salinity (SSS ; in pss). Mean values and standard deviations were calculated for the whole period (all months, from 1998 to 2013, except for MAREL: 20002010, and L4: 2002-2012) and for the winter months (December-January-February, from 1998 to 2013).

Table 2. Pearson correlations between sea surface temperature (SST) anomalies) (SOMLITBrest and SOMLIT-Astan), rain rates anomalies (Guipavas station), and river discharge anomalies (Aulne+Elorn and Penzé) and (1) the teleconnection indices and (2) the weather regimes indices. The explained variability (\%) was assessed using the coefficient of determination $\left(r^{2}\right)$. Weather regimes were calculated from the sea-level pressure (see text). NAO: the North Atlantic Oscillation; EAP: the East Atlantic Pattern; AR: the Atlantic Ridge; BLK: the Scandinavian Blocking regime; NAO+: positive phase of the NAO; NAO-: negative phase of the NAO. Probabilities were corrected to account for temporal autocorrelation. The highest correlations $\left(r^{2}>0.1\right)$ are in bold.

Table 3. Pearson correlations between rain rate anomalies recorded at the Guipavas station, sea surface salinity (SSS) anomalies calculated at the SOMLIT-Brest and SOMLIT-Astan sites and the river discharge anomalies (1) in Brest (the Aulne+Elorn river discharges) and (2) in Astan (the Penzé river discharge). The explained variability (\%) was assessed using the coefficient of determination $\left(\mathrm{r}^{2}\right)$. Probabilities were corrected to account for temporal autocorrelation. n: number of months considered. The highest correlations $\left(r^{2}>0.1\right)$ are in bold.

Table 4. Reconstruction of nutrient concentrations in rivers impacting the Bay of Brest waters. Nitrate and silicic acid concentration in the freshwater end member as determined at the intercept of the y-axis (cf. mixing diagram, Fig. 8, SOMLIT-Brest) is compared to the average concentration in nitrate and silicic acid in the freshwater end member (FEM) as calculated from data of the ECOFLUX database. The Aulne (A) river discharge predominating that of the Elorn (E) by a factor of 4.55, we weighted the river discharges as 
follows: FEM $=0.82 \mathrm{~A}+0.18 \mathrm{E}$. For both nutrients, uncertainty ranges are mentioned between brackets. 


\section{Figure 1}

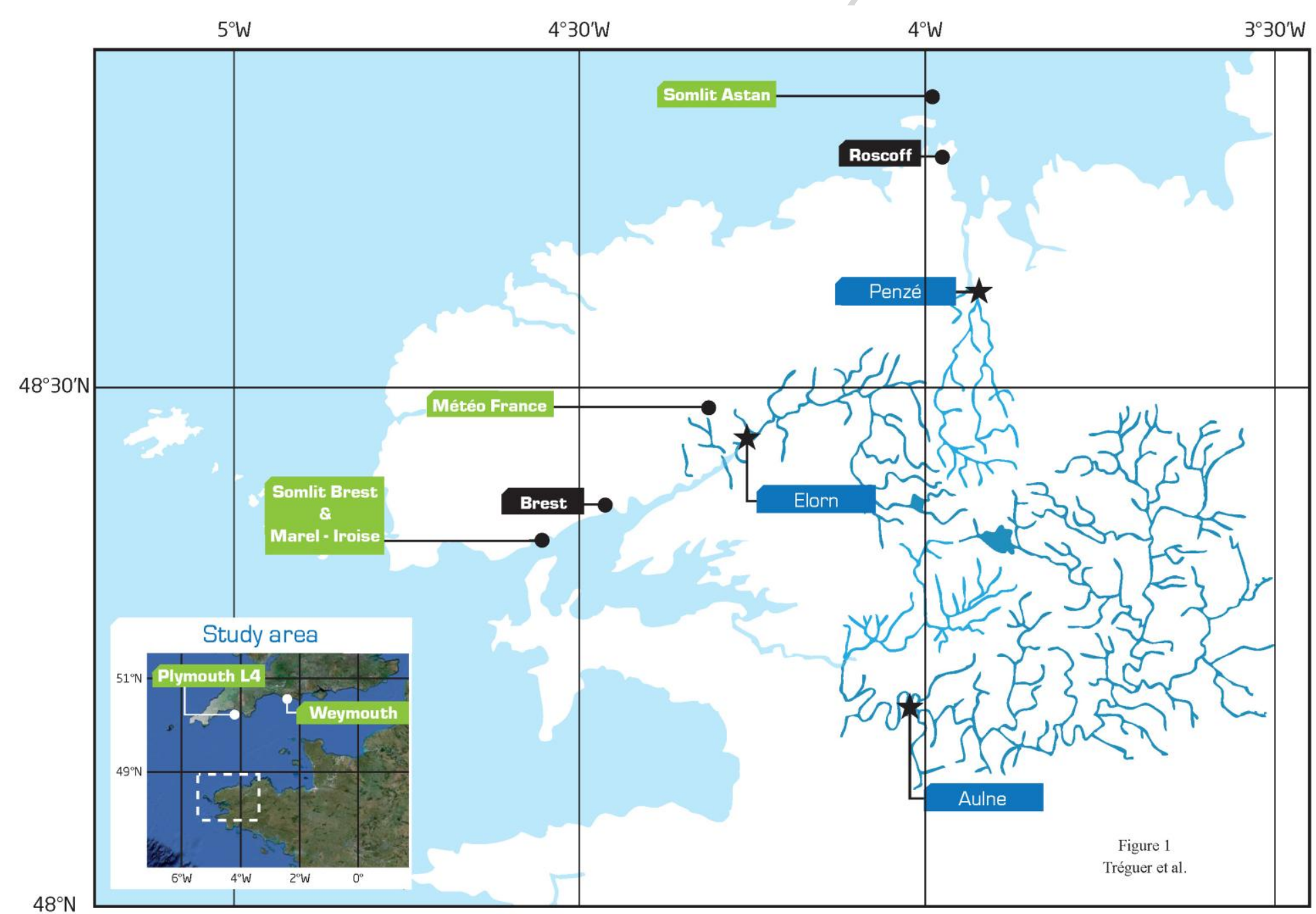


a) NAO

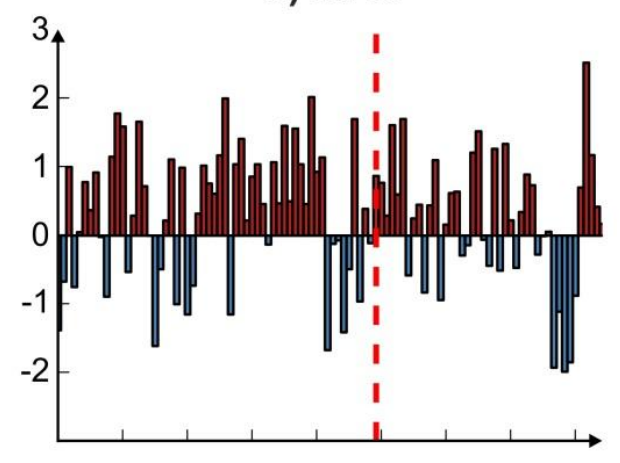

c) NAO+

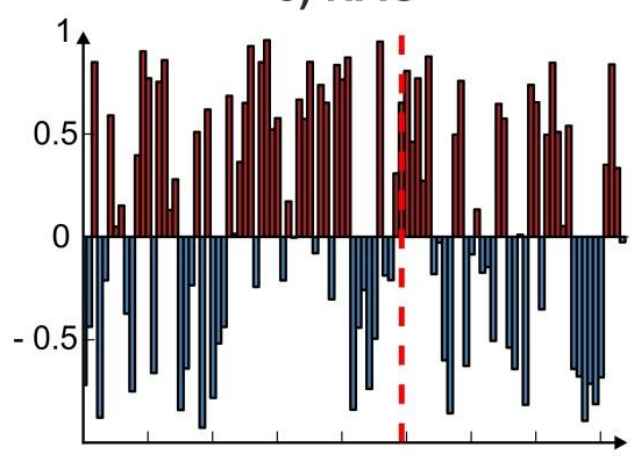

e) NAO-

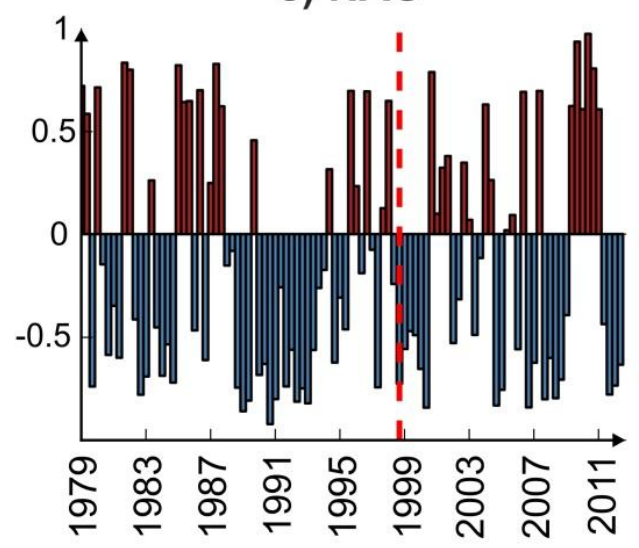

b) EAP (inverted)

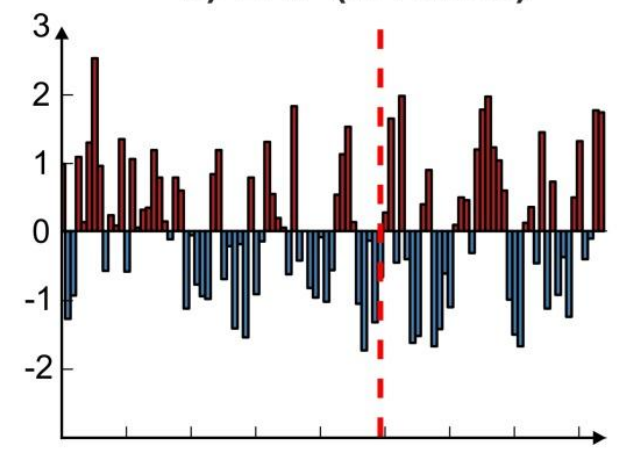

d) AR

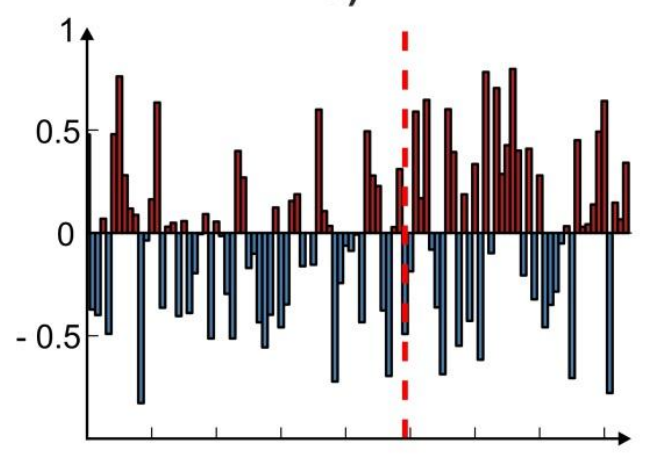

f) BLK

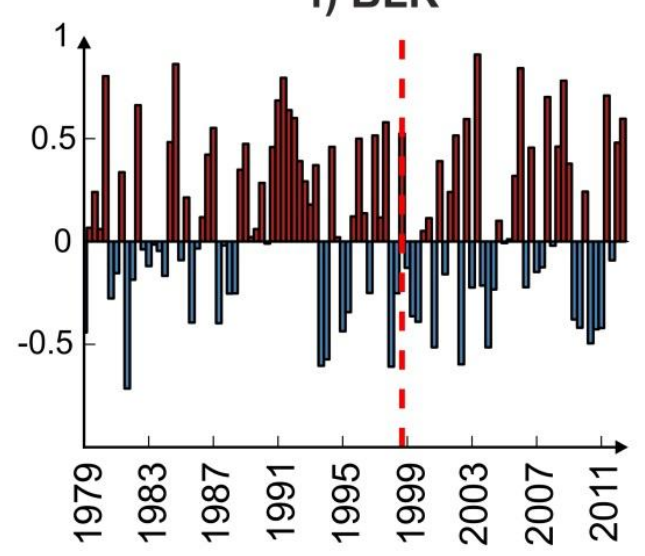

Figure 2

Tréguer et al. 
a) $\mathrm{NAO}+$

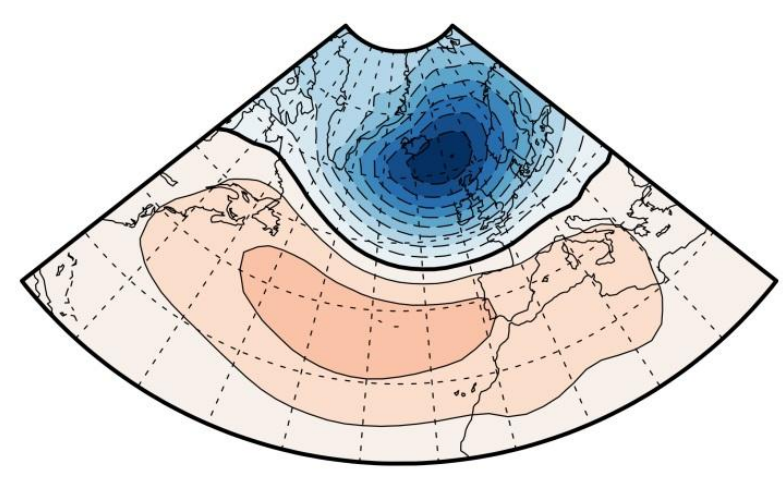

c) BLK

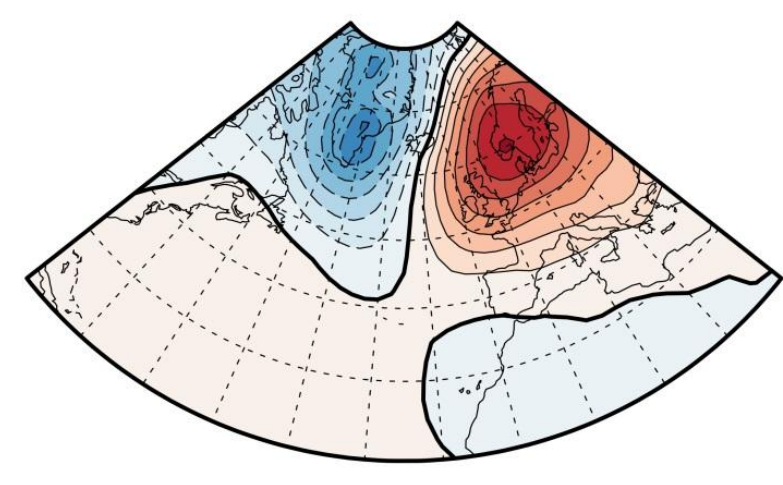

b) NAO-

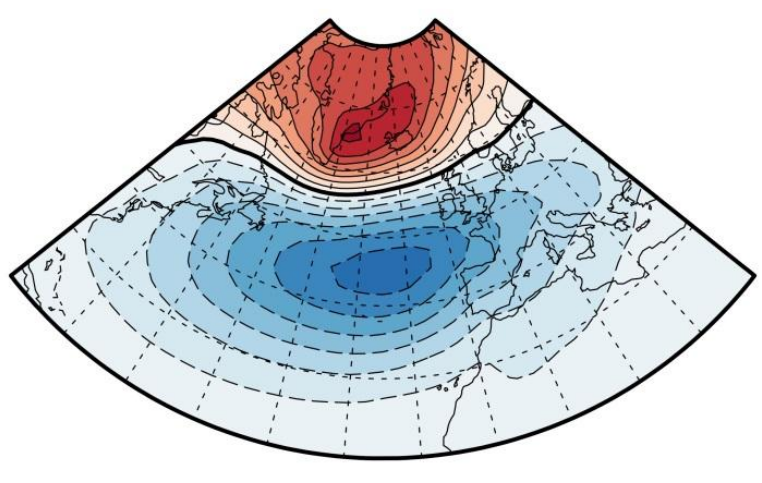

d) AR

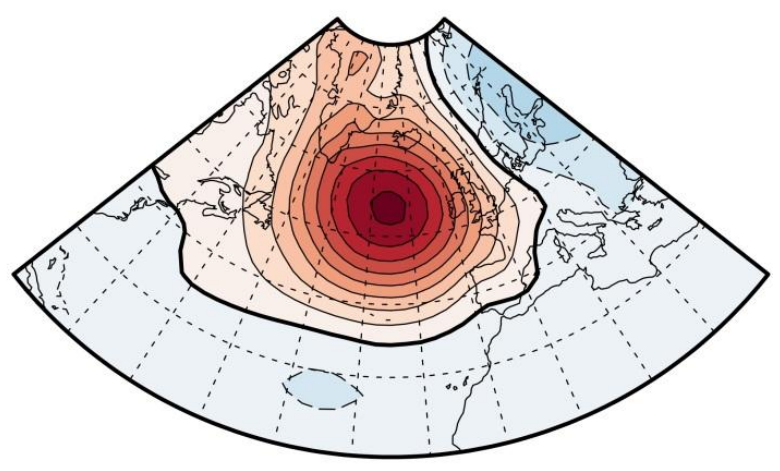

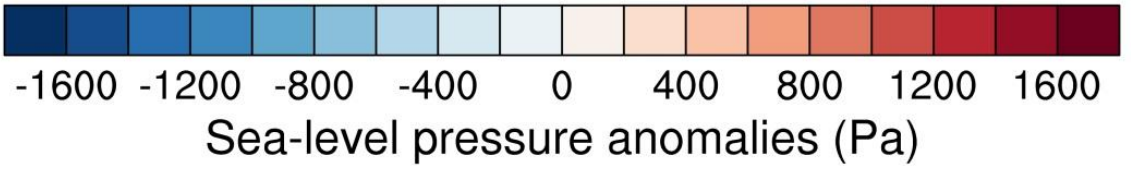

Figure 3

Tréguer et al. 
a)

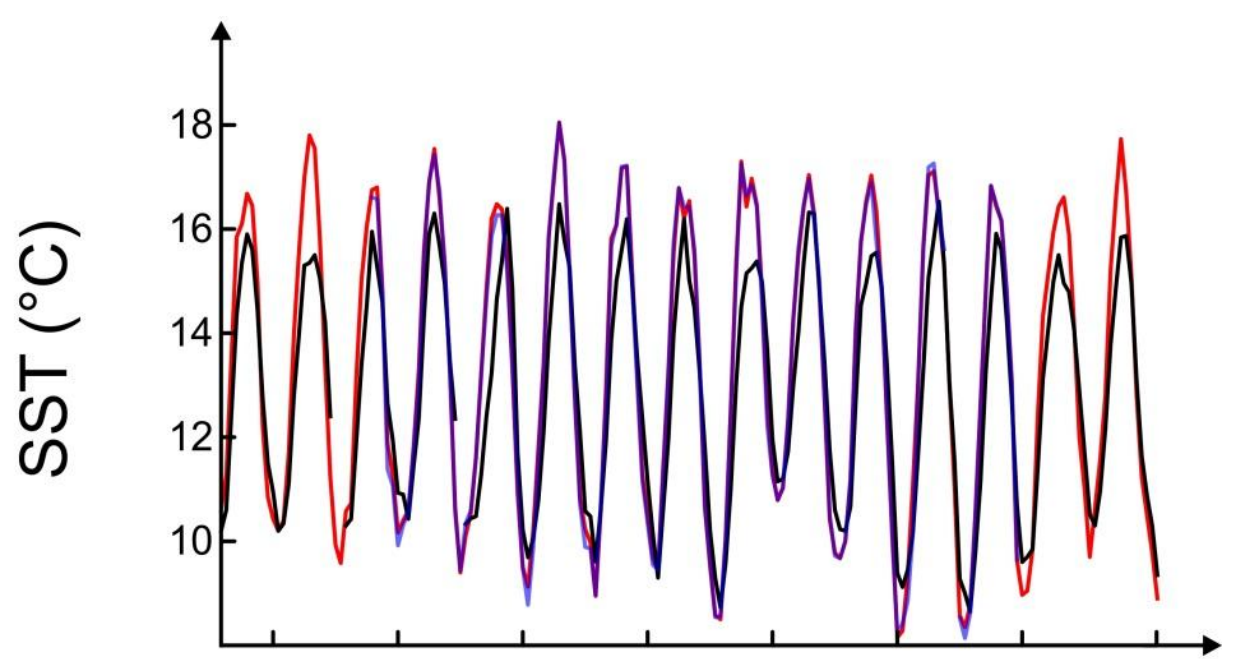

b)

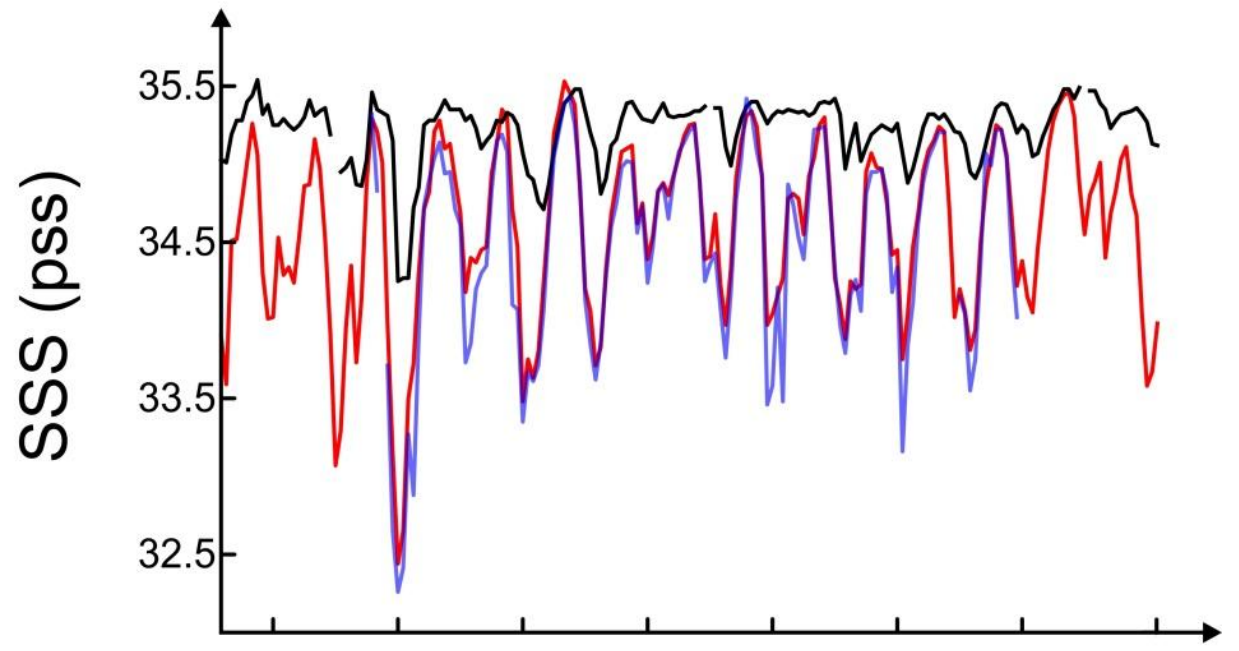

c)

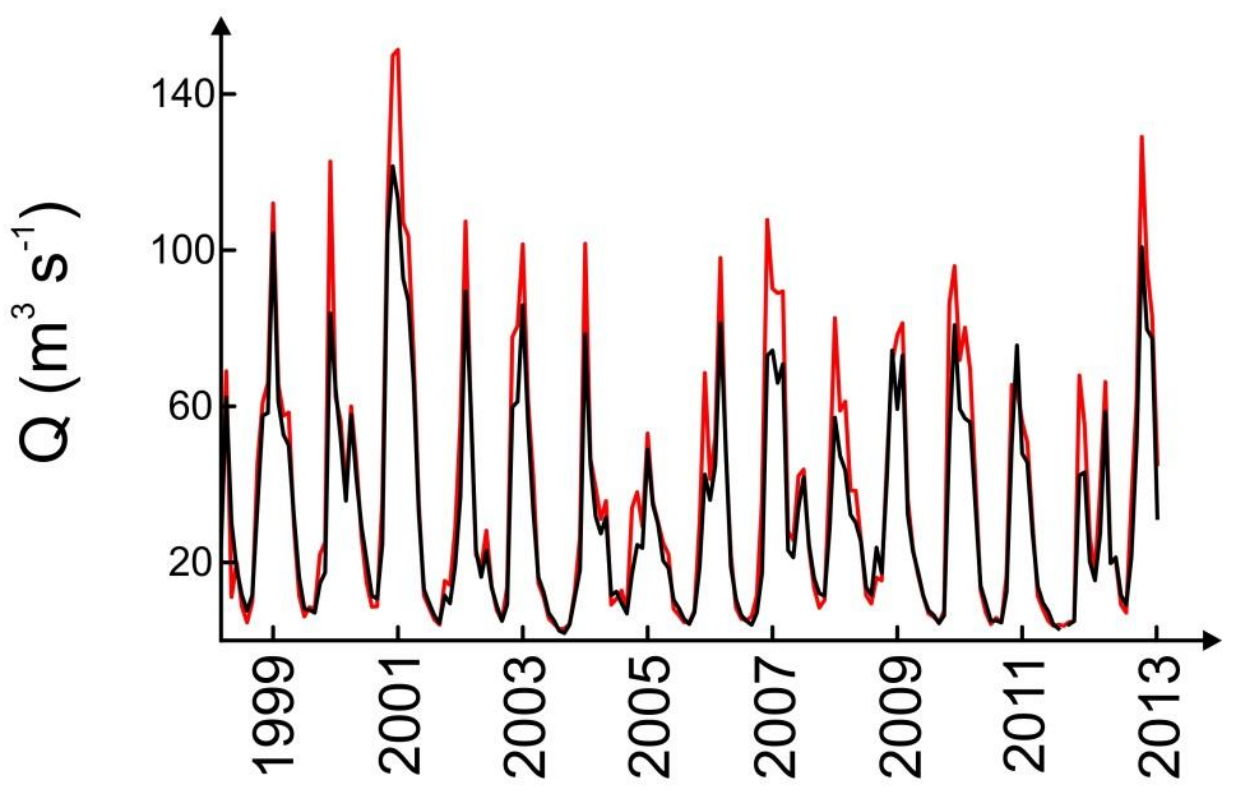

Figure 4

Tréguer et al. 
a)

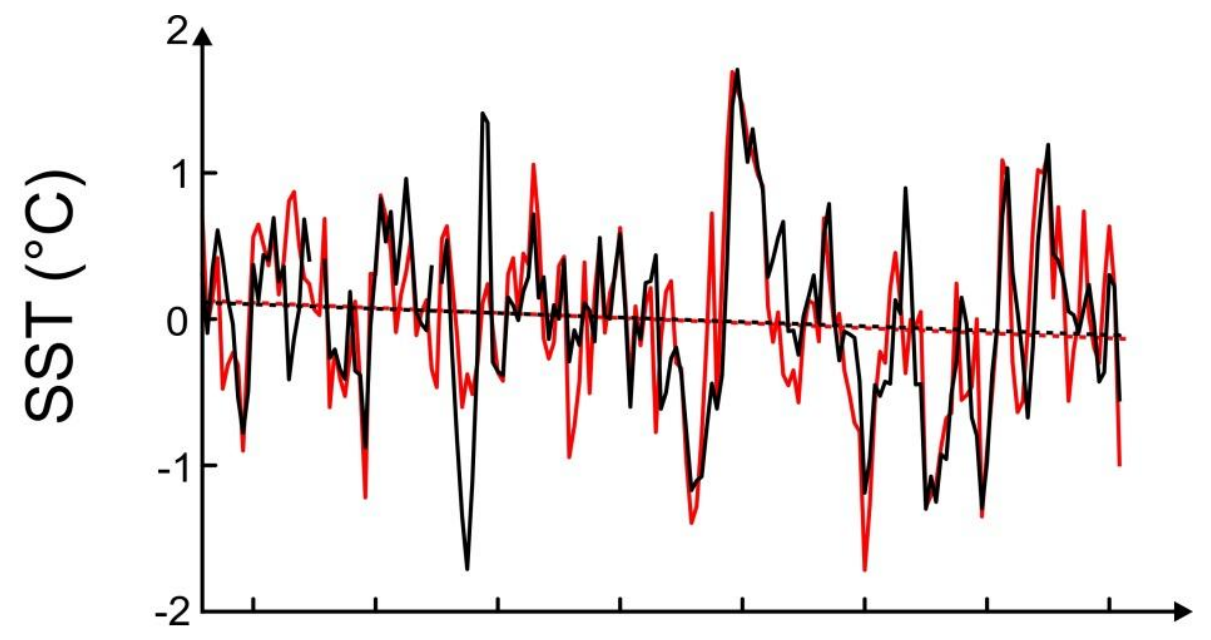

b)

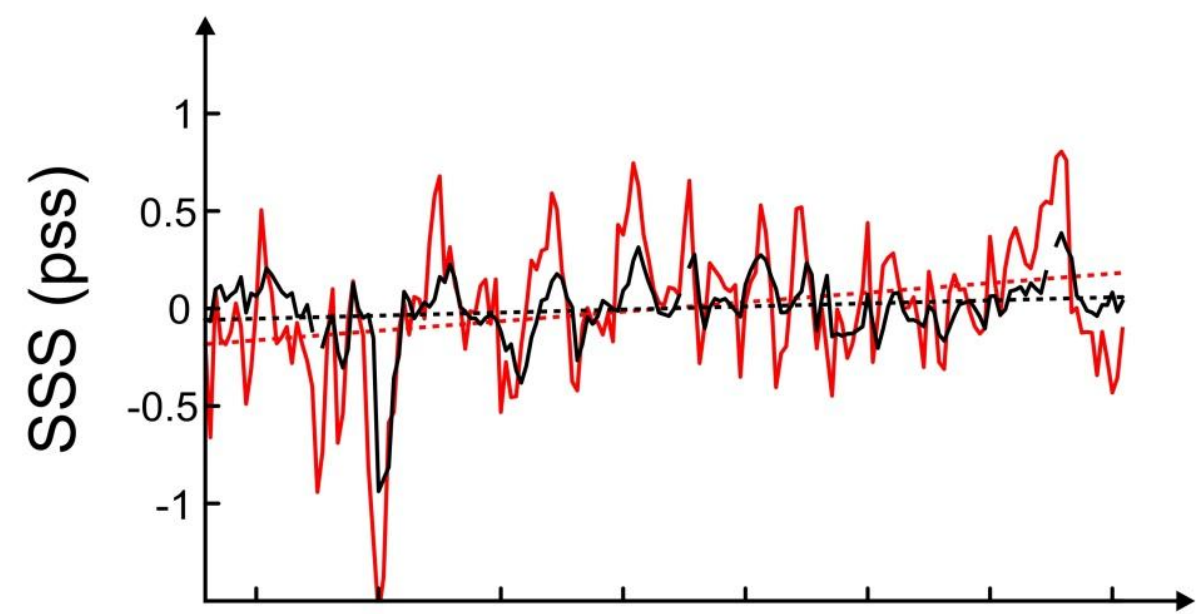

c)

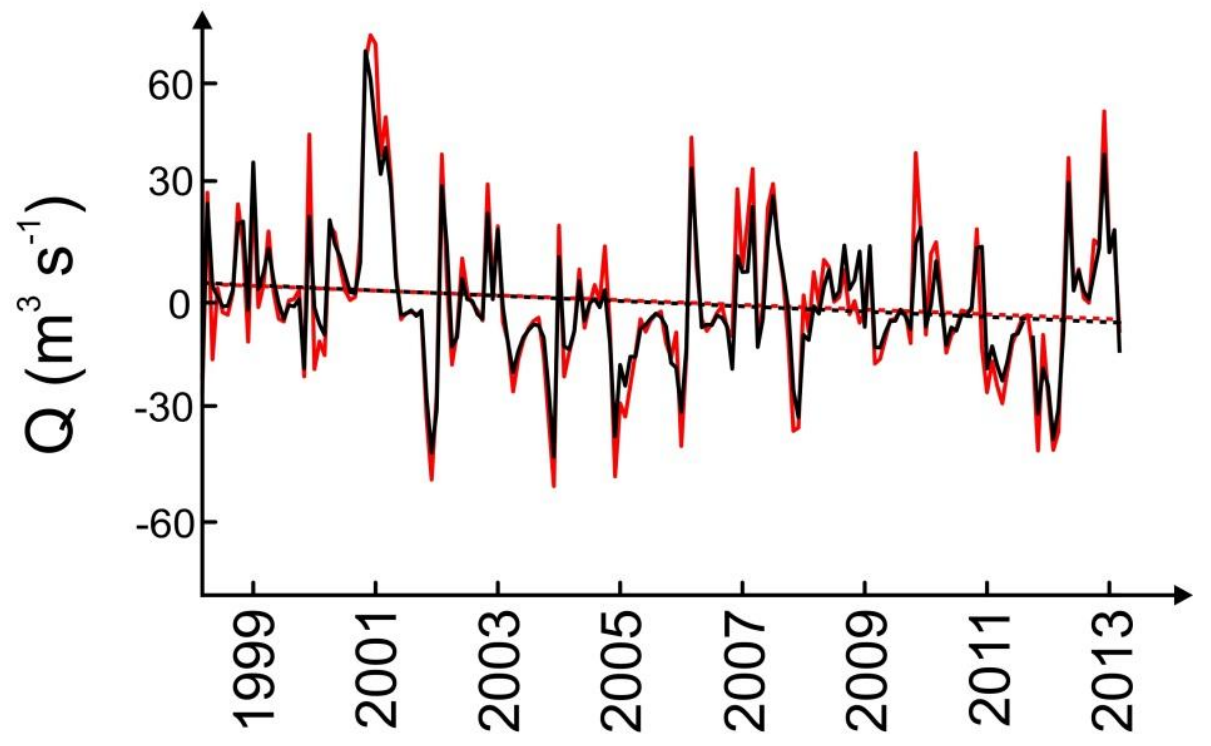

Figure 5

Tréguer et al. 
a)
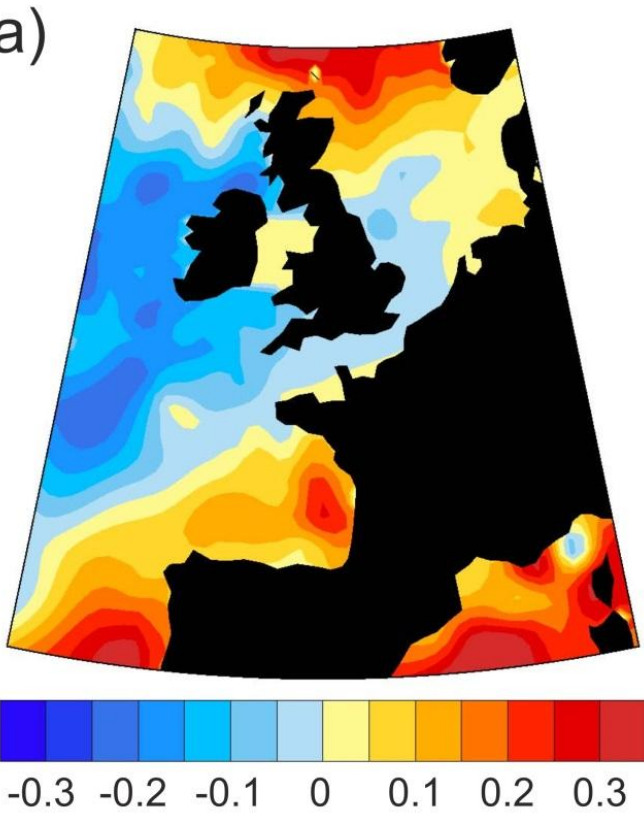

${ }^{\circ} \mathrm{C} /$ decade b)
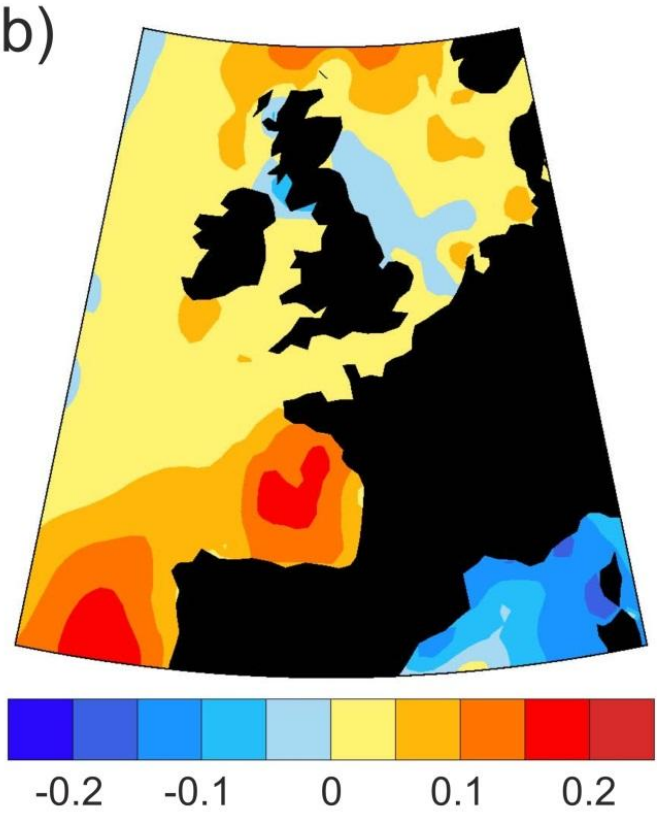

pss / decade

Figure 6

Tréguer et al. 
a) NAO

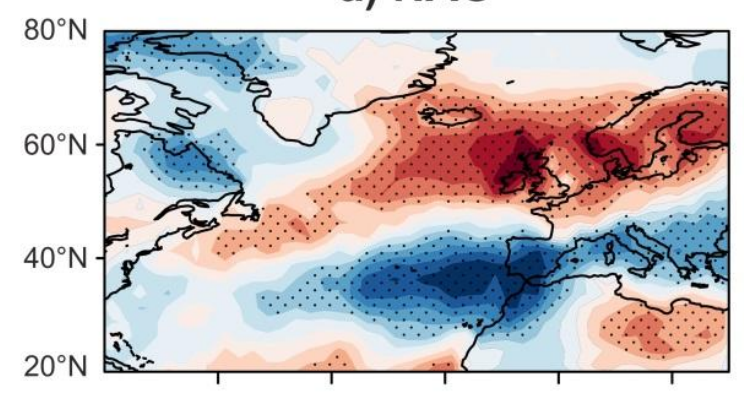

c) NAO+

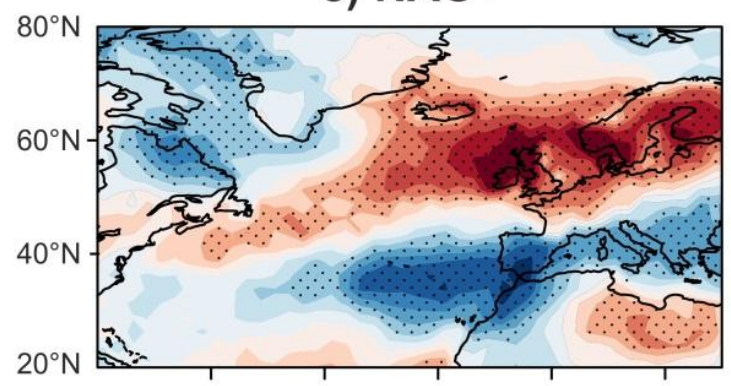

e) NAO-

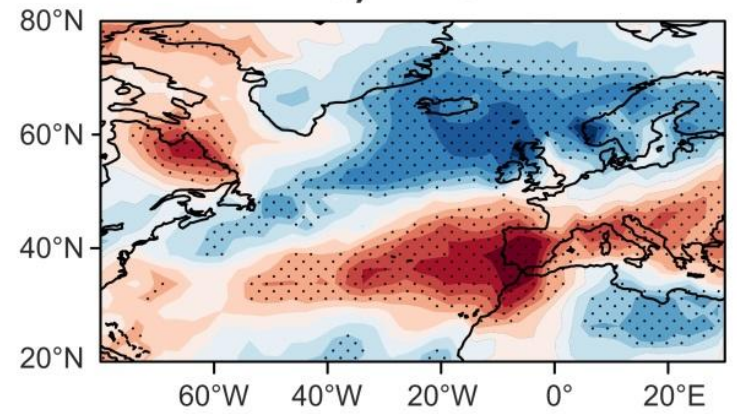

b) EAP (inverted)

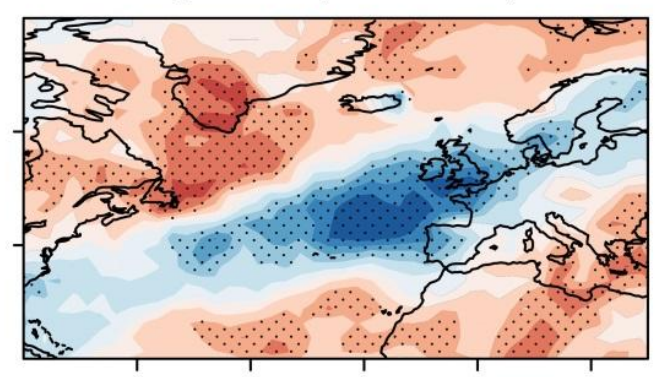

d) AR

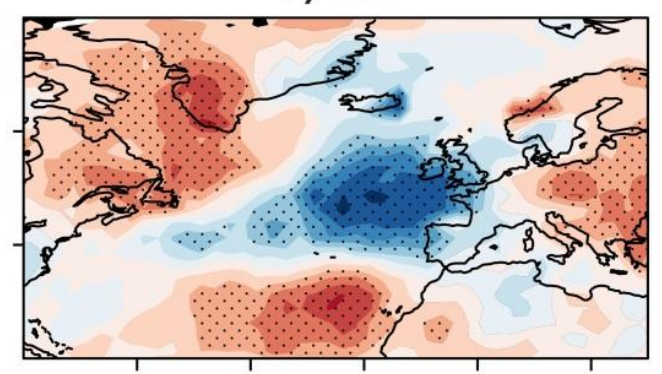

f) BLK

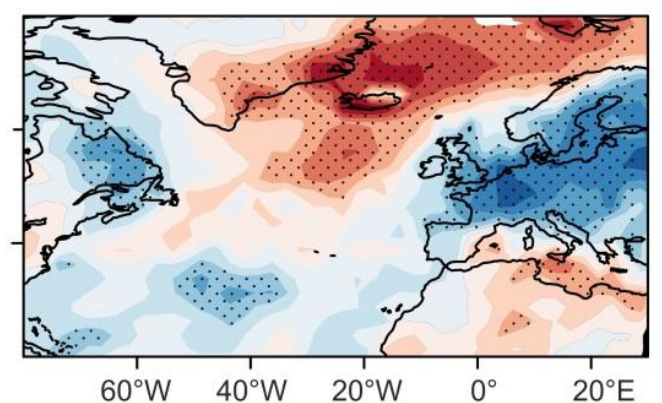

Figure 7

Tréguer et al. 


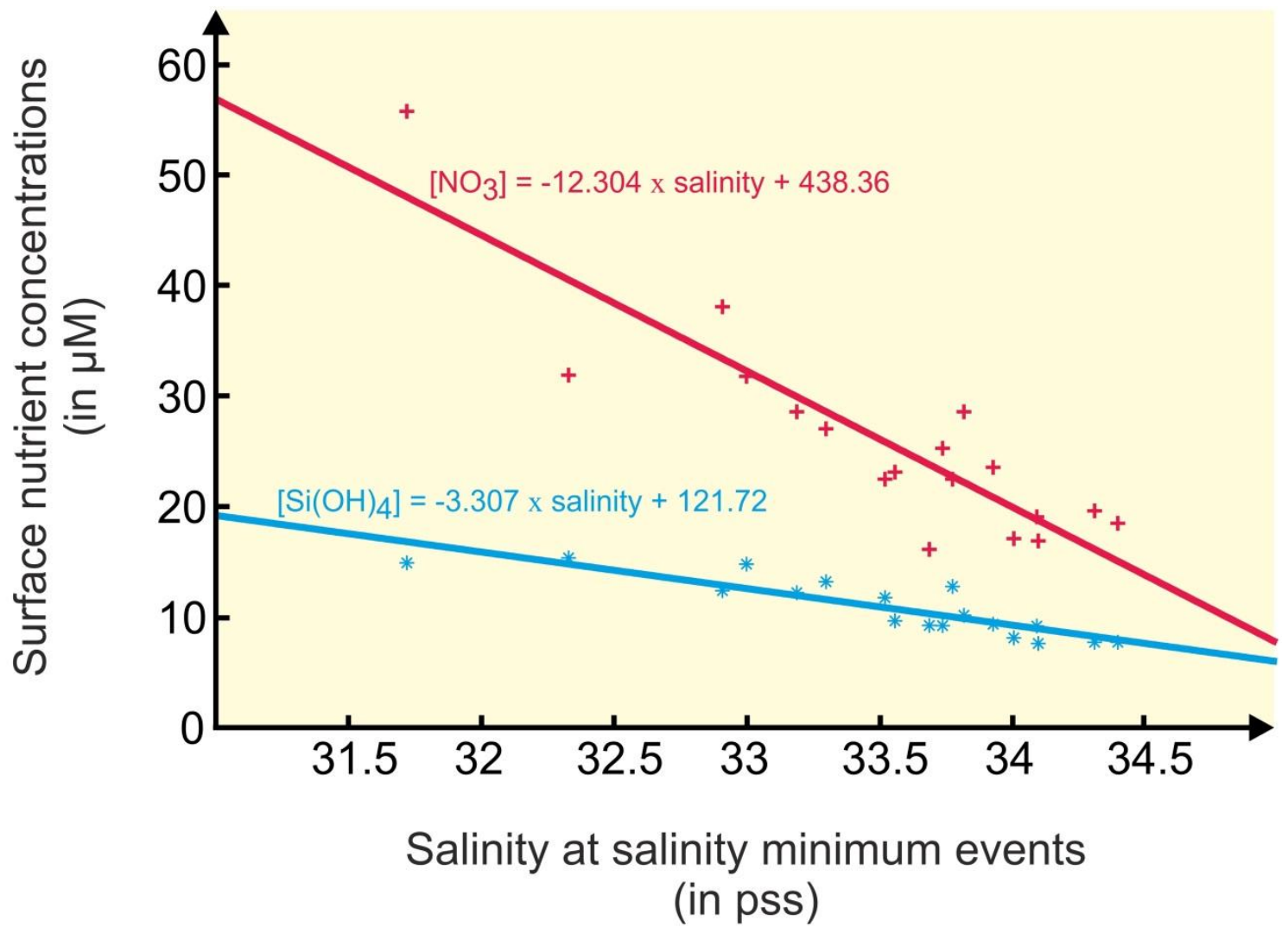

Figure 8

Tréguer et al. 


\begin{tabular}{|c|c|c|c|c|c|c|c|c|}
\hline & \multicolumn{3}{|c|}{ all months } & \multicolumn{3}{|c|}{ winter months } \\
\hline & & & mean & $\min$ & $\max$ & mean & $\min$ & $\max$ \\
\hline \multirow{5}{*}{$\mathscr{\mathscr { S }}$} & & Brest & $13.24 \pm 2.83$ & 8.15 & 18.05 & $10.14 \pm 0.98$ & 8.15 & 12.56 \\
\hline & & Marel & $13.22 \pm 2.92$ & 8.14 & 18.04 & $9.95 \pm 0.98$ & 8.14 & 12.22 \\
\hline & $\underbrace{\mathcal{O}}$ & Astan & $12.85 \pm 2.21$ & 8.65 & 16.53 & $10.91 \pm 1.09$ & 9 & 13.7 \\
\hline & & L4 & $12.65 \pm 2.75$ & 7.77 & 17.92 & $10.14 \pm 1.24$ & 8.15 & 12.49 \\
\hline & & Weymouth & $12.32 \pm 3.73$ & 5.80 & 19.20 & $8.42 \quad \pm 1.31$ & 5.8 & 10.8 \\
\hline & \multirow{4}{*}{$\begin{array}{l}\widehat{\tilde{n}} \\
\tilde{\Xi}\end{array}$} & Brest & $34.59 \pm 0.57$ & 32.44 & 35.53 & $34.12 \pm 0.56$ & 32.44 & 34.9 \\
\hline & & Marel & $34.48 \pm 0.66$ & 32.26 & 35.43 & $33.95 \pm 0.66$ & 32.26 & 34.89 \\
\hline & & Astan & $35.22 \pm 0.21$ & 34.25 & 35.54 & $35.21 \pm 0.25$ & 34.25 & 35.49 \\
\hline & & L4 & $35.39 \pm 0.22$ & 34.01 & 35.39 & $34.96 \pm 0.25$ & 34.38 & 35.37 \\
\hline
\end{tabular}

Table 1

Tréguer et al. 


\begin{tabular}{|c|c|c|c|c|c|c|c|c|c|c|c|c|c|c|c|c|c|c|}
\hline & \multicolumn{6}{|c|}{ (1) Teleconnection indices } & \multicolumn{12}{|c|}{ (2) Weather regimes } \\
\hline & \multicolumn{3}{|c|}{ NAO } & \multicolumn{3}{|c|}{ EAP } & \multicolumn{3}{|c|}{$\mathrm{AR}$} & \multicolumn{3}{|c|}{ BLK } & \multicolumn{3}{|c|}{$\mathrm{NAO+}$} & \multicolumn{3}{|c|}{ NAO- } \\
\hline & $\mathrm{r}$ & $\%$ & $\mathrm{p}$ & $\mathrm{r}$ & $\%$ & $\mathrm{p}$ & $\mathrm{r}$ & $\%$ & $\mathrm{p}$ & $\mathrm{r}$ & $\%$ & $\mathrm{p}$ & $\mathrm{r}$ & $\%$ & $\mathrm{p}$ & $\mathrm{r}$ & $\%$ & $\mathrm{p}$ \\
\hline $\begin{array}{c}\text { SST } \\
\text { (SOMLIT-Brest) } \\
\end{array}$ & 0.484 & 23.43 & 0.004 & 0.088 & 0.77 & 0.615 & 0.042 & 0.18 & 0.792 & -0.095 & 0.90 & 0.549 & 0.428 & 18.32 & 0.016 & -0.344 & 11.83 & 0.058 \\
\hline $\begin{array}{c}\text { SST } \\
(\text { SOMLIT-Astan }) \\
\end{array}$ & 0.560 & 31.36 & 0.001 & 0.039 & 0.15 & 0.835 & 0.037 & 0.14 & 0.822 & 0.041 & 0.17 & 0.806 & 0.466 & 21.72 & 0.011 & -0.452 & 20.43 & 0.018 \\
\hline $\begin{array}{c}\text { Rain rate anomalies } \\
\text { (Guipavas) }\end{array}$ & 0.026 & 0.07 & 0.866 & 0.673 & 45.29 & $<0.001$ & -0.485 & 23.52 & 0.001 & -0.278 & 7.73 & 0.075 & 0.195 & 3.80 & 0.216 & 0.187 & 3.50 & 0.236 \\
\hline $\begin{array}{c}\text { River discharge } \\
\text { Brest }(\text { Aulne }+ \text { Elorn })\end{array}$ & -0.094 & 0.87 & 0.571 & 0.594 & 35.28 & $<0.001$ & -0.307 & 9.41 & 0.048 & -0.383 & 14.70 & 0.012 & 0.060 & 0.36 & 0.726 & 0.291 & 8.44 & 0.086 \\
\hline $\begin{array}{c}\text { River discharge } \\
\text { Astan (Penzé) }\end{array}$ & -0.152 & 2.30 & 0.364 & 0.478 & 22.89 & $<0.001$ & -0.207 & 4.28 & 0.189 & -0.406 & 16.51 & 0.007 & 0.009 & 0.01 & 0.960 & 0.306 & 9.36 & 0.073 \\
\hline
\end{tabular}

Table 2

Tréguer et al. 


\begin{tabular}{c|cccc|cccc} 
& \multicolumn{4}{|c|}{$\begin{array}{c}\text { Rain rate anomalies } \\
\text { (Guipavas) }\end{array}$} & \multicolumn{4}{c}{ SSS anomalies } \\
\hline River discharge & $\mathrm{r}$ & $\mathrm{p}$ & $\begin{array}{c}\text { explained } \\
\text { variability (in \%) }\end{array}$ & $\mathrm{n}$ & $\mathrm{r}$ & $\mathrm{p}$ & $\begin{array}{c}\text { explained } \\
\text { variability (in \%) }\end{array}$ & $\mathrm{n}$ \\
\hline Brest (Aulne + Elorn) & $\mathbf{0 . 7 6 2}$ & $<0.001$ & $\mathbf{5 8 . 0 6}$ & 43 & $\mathbf{- 0 . 7 0 6}$ & $<0.001$ & $\mathbf{4 9 . 8 4}$ & 43 \\
Astan (Penzé) & $\mathbf{0 . 6 1 0}$ & $<0.001$ & $\mathbf{3 7 . 2 1}$ & 43 & $\mathbf{- 0 . 5 0 7}$ & 0.002 & $\mathbf{2 4 . 1 9}$ & 43
\end{tabular}

Table 3

Tréguer et al. 


\begin{tabular}{c|c|c} 
& $\begin{array}{c}\mathrm{Si}(\mathrm{OH})_{4} \\
(\mathrm{in} \mu \mathrm{M})\end{array}$ & $\begin{array}{c}\mathrm{NO}_{3} \\
(\mathrm{in} \mu \mathrm{M})\end{array}$ \\
\hline $\begin{array}{c}\text { Intercept y-axis } \\
\text { (from Fig. 8) } \\
\text { Aulne } \\
\text { (mean concentration) }\end{array}$ & $122( \pm 15)$ & $438( \pm 53)$ \\
$\begin{array}{c}\text { Elorn } \\
(\text { mean concentration) }\end{array}$ & $144( \pm 7)$ & $402( \pm 53)$ \\
$\begin{array}{c}\text { FEM } \\
(\text { mean concentration) } \\
(0.82 \text { A + 0.18 E) } \\
\text { Intercept - FEM } \\
(\text { mean concentration) }\end{array}$ & $151( \pm 7)$ & $558( \pm 56)$ \\
$\begin{array}{c}\text { Intercept - FEM }) / \text { FEM } \\
(\%)\end{array}$ & $-23( \pm 7)$ & $435( \pm 54)$ \\
& $16 \%$ & $<3( \pm 54)$ \\
\end{tabular}

Table 4

Tréguer et al. 